\title{
Bioextraction potential of seaweed in Denmark - An instrument for circular nutrient management
}

\author{
Michele Seghetta ${ }^{\mathrm{a}}$, Ditte Tørring ${ }^{\mathrm{b}}$, Annette Bruhn ${ }^{\mathrm{c}}$, Marianne Thomsen ${ }^{\mathrm{a}, *}$

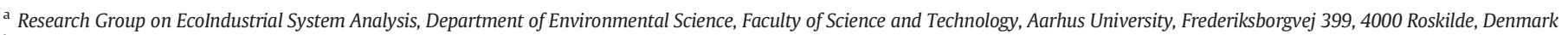 \\ b Orbicon A/S, Jens Juuls Vej 16, 8260 Viby, Denmark \\ c Department of Bioscience, Faculty of Science and Technology, Aarhus University, Vejlsøvej 25, 8600 Silkeborg, Denmark
}

\section{H I G H L I G H T S}

- Offshore seaweed production for nutrient circular management is assessed.

- The impact of different management strategies on eutrophication is calculated.

- LCA of nutrient and biomass management strategies is developed.

- Seaweed bioextraction of nutrients is a key for circular resource management.

- Seaweed cultivation is an instrument to achieve national water quality goals.
G R A P H I C A L A B S T R A C T

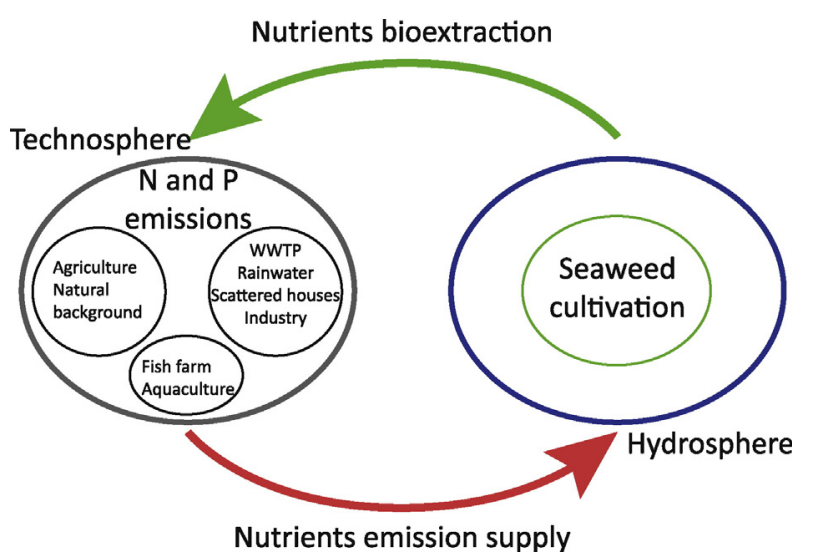

\section{A B S T R A C T}

The aim of the study is to assess the efficacy of seaweed for circular nutrient management to reduce eutrophication levels in the aquatic environment. We performed a comparative Life Cycle Assessment (LCA) of two reference waste management systems treating seaweed as biowaste, i.e. landfill disposal and combustion, and an alternative scenario using the seaweed Saccharina latissima as a resource for biobased fertilizer production. Life Cycle Impact Assessment (LCIA) methods were improved by using a cradle-to-cradle approach, quantifying fate factors for nitrogen and phosphorus loss from fertilized agriculture to the aquatic environment. We also differentiated between nitrogen- and phosphorus-limited marine water to improve the traditional freshwater impact category, making this indicator suitable for decision support in relation to coastal water management schemes. Offshore cultivation of Saccharina latissima with an average productivity of $150 \mathrm{Mg} / \mathrm{km}^{2}$ in Danish waters in 2014 was applied to a cultivation scenario of $208 \mathrm{~km}^{2}$. The bioresource scenario performs better than conventional biowaste management systems, delivering a net reduction in aquatic eutrophication levels of $32.29 \mathrm{~kg} \mathrm{~N}$ eq. and $16.58 \mathrm{~kg} \mathrm{PO}_{4}^{3-}$ eq. per $\mathrm{Mg}$ (dry weight) of seaweed, quantified by the ReCiPe and CML impact assessment methods, respectively. Seaweed cultivation, harvest and reuse of excess nutrients from the aquatic environment is a promising approach for sustainable resource cycling in a future regenerative economy that exploits manmade emissions as a resource for closed loop biobased production while significantly reducing

\footnotetext{
* Corresponding author.

E-mail address: mth@envs.au.dk (M. Thomsen).
} 
eutrophication levels in 3 out of 7 Danish river basin districts. We obtained at least 10\% bioextraction of phosphorus manmade emissions ( $10 \%, 89 \%$ and $>100 \%$ ) and contributed significantly to local nitrogen reduction goals according to the Water Framework Directive (23\%, $78 \%$ and $>100 \%$ of the target).

(c) 2016 Elsevier B.V. All rights reserved.

\section{Introduction}

Marine biomass accounts for over $50 \%$ of the primary production of global biomass (Carlsson et al., 2007). Compared to terrestrial biomass, only a small fraction of this is used for production. Coastal ecosystems, which cover $<0.5 \%$ of the sea bed, capture $55 \%$ of world green (biological) carbon (Nellemann et al., 2009).

This fundamental service is endangered by linear production systems characterized by one-way flow of nutrients, i.e. manmade emissions, from the lithosphere to the hydrosphere, resulting in excess nitrogen and phosphorus that give rise to eutrophication of natural marine and freshwater ecosystems. Manmade emissions are nutrients lost to marine water bodies from Danish land-based activities, e.g. $\mathrm{NO}_{3}^{-}$from agriculture, $\mathrm{NH}_{3}^{+}$from fish farming; here referred as "emission supply to seaweed cultivation".

Green-engineered nutrient bioextraction, presented in this study as offshore seaweed production systems floating in open waters, may be used to mitigate continuing eutrophication of marine systems. Cultivation of seaweed in green-engineered open water systems, i.e. on an artificial substrate (ropes deployed in marine water), is isolated from natural habitats since it does not compete with the natural benthic community for the occupation of the sea bottom (Buschmann et al., 2014; Zhang et al., 2009).

Such biobased production systems are a key for transforming linear production systems into circular systems. Engineered production of blue carbon is a circular nutrient management system using landbased emission as a resource for biobased production, thus contributing to restoration of biogeochemical balance. Offshore cultivation of seaweed is a relatively new technology in Europe (www.netalgae.eu), but is developing rapidly and attracting funding in northern European countries such as Denmark (e.g. www.MAB3.dk, www.submarinerproject.eu), the Netherlands, Ireland and Scotland (e.g. www. noordzeeboerderij.nl, www.enalgae.eu, www.atsea-project.eu, www. biomara.org).

Conceiving emissions as a resource for seaweed cultivation, if successfully implemented, may be a key green-engineered system for future sustainable blue growth (COM, 2012; Quilliam et al., 2015). Furthermore, seaweed production and utilization is compatible with the circular economy principle of transforming CCS into carbon capture and use (CCU) by biobased production systems. In this regard, it is important to evaluate the key factors making engineered seaweed cultivation systems sustainable with respect to restoration of marine environmental conditions supporting the conservation of natural ecosystem services (Nellemann et al., 2009).

In this study we consider the most simple and immediate example of how seaweed can transform emissions into bioresources, establishing a circular flow through using harvested seaweed biomass as fertilizer. Loss of nutrients from the lithosphere to the hydrosphere is therefore reduced by returning them to soil. Denmark used cast seaweed as soil fertilizer and conditioner in the 19th century, a practice which has also been popular in other parts of the world, e.g. Spain and Ireland (Villares et al., 2007; Mouritsen, 2013). Seaweed enhances soil quality by improving soil texture and water retention (Craigie, 2011). It also enhances soil microbial biomass and soil respiration rate (Haslam and Hopkins, 1996). The value of the world's seaweed industries producing agrochemicals (fertilizers and biostimulants) is estimated at about US\$ $10 \mathrm{~m}$ (Craigie, 2011).

The purpose of this paper is: 1) to evaluate the impact of seaweed production and utilization on aquatic eutrophication and 2) to assess to what extent it is possible to counterbalance yearly manmade emissions with a seaweed bioextraction system.

To meet the first aim we perform a Life Cycle Assessment (LCA) on the production and use of seaweed, considering Denmark as case study. For the second aim we compare the bioextraction potential of seaweed with yearly manmade emissions for three different time horizons, taking Denmark as case study.

\section{Goal and scope}

We performed comparative LCA of three scenarios for production and utilization of seaweed biomass. The goal of the LCA is to evaluate the impact of three different seaweed biomass management options on aquatic eutrophication (Fig. 1): one scenario applies the bioresource management option, in which 1. macroalgae used as fertilizer (MaFe); the others use two existing disposal options: 2. landfilling and 3. incineration.

The MaFe scenario is a simple system for circular nutrient management to maintain ecosystem health and promote biobased production. Excess nitrogen and phosphorus from agriculture entering marine water bodies are bioextracted by seaweed growth. The seaweed-based fertilizer is then returned to the soil for crop production. Thus a quantity of mineral $\mathrm{N}$ and $\mathrm{P}$ fertilizer is substituted, reducing fossil resource depletion (Niero et al., 2014; Jensen et al., 2015).

The choice of including incineration and landfilling scenarios is based on the fact that seaweed biomass composition varies during the year and from place to place (Bruhn et al., 2016; Nielsen et al., 2016). It is therefore possible that the concentration of heavy metals may exceed the limit allowed for return to the soil as regulated by the European Sludge Directive (Sludge Directive 86/278/EEC) or Statutory Order no. 1650 (Sludge order), e.g. Cd $>0.8 \mathrm{mg} / \mathrm{kg}$ dry matter (Seghetta et al., 2016a). In such cases, incineration with energy recovery or landfill are the common management options, e.g. for beach-cast seaweed (Kaspersen et al., 2016; Fredenslund et al., 2010; Seghetta et al., 2014).

The results are presented for a functional unit of $1 \mathrm{Mg}$ dry weight (DW) of seaweed biomass produced per year.

The system boundaries are drawn to include all the inputs from cradle to cradle, i.e. seaweed cultivation, in the case of the biofertilizer production system 1 (MaFe), or to grave, in case of waste management systems 2 and 3 (Fig. 1). Emissions to water from manmade activities, e.g. agriculture, are excluded from the system boundaries of the LCA. Only emissions related to production, processing and disposal of seaweed are included.

The calculation was performed using the software SimaPro 8.0.4 (PRé consultants, 2008) and the integrated inventory Ecoinvent v3.1 (Weidema et al., 2013). The Life Cycle Inventory is described in detail in Section 3.

\section{Life Cycle Inventory (LCI)}

The Life Cycle Inventory for the system includes nutrient bioextraction during seaweed cultivation, during which element bioextraction occurs, transport for: 1. pretreatment for biofertilizer production and use; 2. landfilling; 3. incineration with energy production and associated emissions to air and water (Fig. 1). The collected data is presented in Tables 1 and 2. 


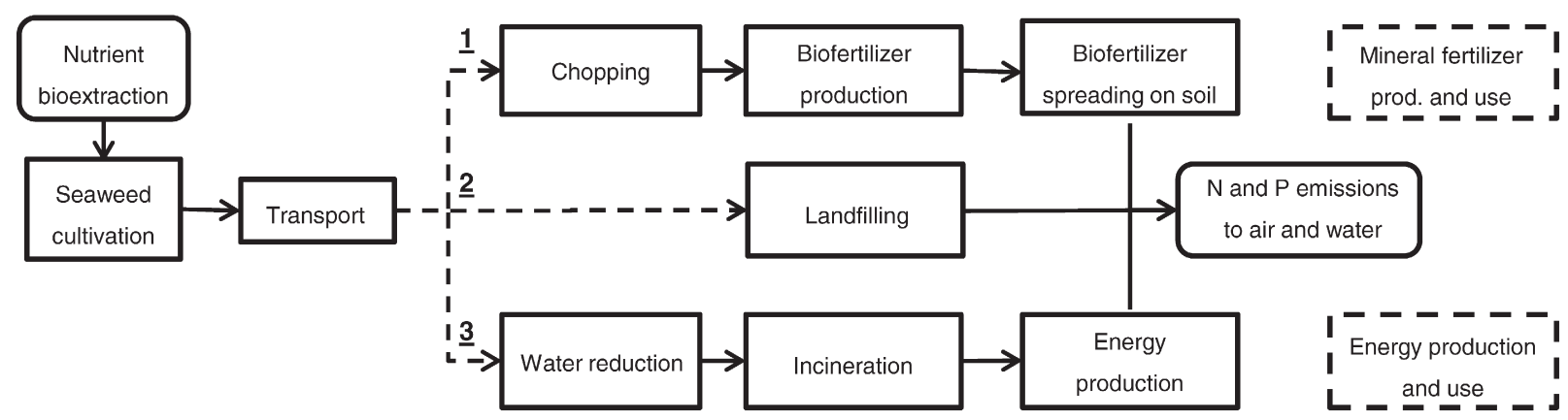

\section{Macroalgae production}

Bioresource / waste management options

Substituted products

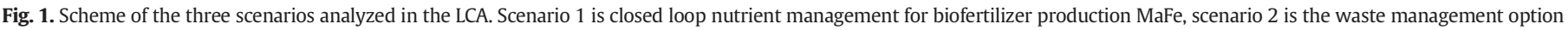
landfilling, and scenario 3 is Incineration with energy production. Seaweed cultivation and transport are common phases for all three scenarios.

\subsection{Seaweed production}

Information regarding seaweed cultivation and the design of the artificial growth substrate is based on a real site located in Limfjorden, Denmark, where Saccharina latissima is produced. The cultivation includes the seed line production phase, the deployment phase, maintenance during the growth phase, and harvest described in more detail in Tørring and Oddershede-Nielsen (2014). In the first phase, kuralone ropes are seeded with Saccharina latissima spores and incubated in a cold room where nutrients and sterile water, at a constant temperature of $10{ }^{\circ} \mathrm{C}$, support their growth (Edwards and Watson, 2011). In the second phase the seeded lines are looped on $8 \mathrm{~mm}$ diameter ropes and deployed in the sea in September. The growth phase continues until April, when the seaweed is harvested; this is one production

Table 1

Life Cycle Inventory for the three management scenarios: seaweed used as fertilizer (MaFe), landfilling and incineration.

\begin{tabular}{|c|c|c|c|c|c|}
\hline \multirow{2}{*}{ Phase } & \multicolumn{3}{|c|}{ Seaweed management scenarios } & \multirow{2}{*}{ U.M./Mg DW seaweed } & \multirow{2}{*}{ Emission sub-compartment } \\
\hline & MaFe & Landfill & Incineration & & \\
\hline \multicolumn{6}{|l|}{ Bioextraction } \\
\hline $\mathrm{N}$ & 32.45 & 32.45 & 32.45 & $\mathrm{~kg}$ & \\
\hline $\mathrm{P}$ & 2.92 & 2.92 & 2.92 & $\mathrm{~kg}$ & \\
\hline \multicolumn{6}{|l|}{ Transport } \\
\hline shore-destination & 30.00 & 30.00 & 30.00 & tkm & \\
\hline \multicolumn{6}{|l|}{ Pretreatment } \\
\hline Chopping & 0.13 & & & MWh & \\
\hline Water reduction & & & 0.01 & $\mathrm{~m} 3$ & \\
\hline \multicolumn{6}{|l|}{ Capture \& reuse/end of life } \\
\hline Biomass spread & 6.67 & & & Mg FW & \\
\hline Biomass to landfill & & 6.67 & & Mg FW & \\
\hline Biomass to incinerator & & & 6.67 & Mg FW & \\
\hline \multicolumn{6}{|l|}{ Emissions to air } \\
\hline Ammonia & 0.23 & 0.01 & 0.01 & $\mathrm{~kg}$ & \\
\hline Dinitrogen monoxide & 0.51 & 0.04 & 0.04 & $\mathrm{~kg}$ & \\
\hline Nitrogen oxides & & 0.00 & 0.25 & $\mathrm{~kg}$ & \\
\hline Phosphorus & & 0.00003 & 0.0005 & $\mathrm{~kg}$ & \\
\hline Cyanide & & 0.00009 & 0.0052 & $\mathrm{~kg}$ & \\
\hline \multicolumn{6}{|l|}{ Emissions to water } \\
\hline Ammonium, ion & & 6.56 & & $\mathrm{~kg}$ & Groundwater \\
\hline Ammonium, ion & & 7.93 & 1.50 & $\mathrm{~kg}$ & River \\
\hline Nitrate & & 0.71 & 0.21 & $\mathrm{~kg}$ & Groundwater \\
\hline Nitrate & & 28.89 & 6.89 & $\mathrm{~kg}$ & River \\
\hline Nitrite & & 0.36 & & $\mathrm{~kg}$ & Groundwater \\
\hline Nitrite & & 0.17 & & $\mathrm{~kg}$ & River \\
\hline Nitrogen & & 0.22 & 0.10 & $\mathrm{~kg}$ & River \\
\hline Nitrogen, organic bond & & 10.70 & & $\mathrm{~kg}$ & Groundwater \\
\hline Phosphate & & 0.06 & 0.06 & $\mathrm{~kg}$ & Groundwater \\
\hline Phosphate & & 0.05 & 0.005 & $\mathrm{~kg}$ & River \\
\hline Nitrogen & 2.30 & & & $\mathrm{~kg}$ & Freshwater $^{*}$ \\
\hline Phosphorus & 0.07 & & & $\mathrm{~kg}$ & Freshwater* \\
\hline Nitrogen & 2.06 & & & $\mathrm{~kg}$ & Marine water ${ }^{* *}$ \\
\hline Phosphorus & 0.07 & & & $\mathrm{~kg}$ & Marine water ${ }^{* *}$ \\
\hline \multicolumn{6}{|l|}{ Substituted products } \\
\hline Electricity & & & 0.95 & MWh & \\
\hline Production $\mathrm{N}$ fert & 22.39 & & & $\mathrm{~kg}$ & \\
\hline Production P fert & 2.77 & & & $\mathrm{~kg}$ & \\
\hline Spreading & 0.30 & & & ha & \\
\hline
\end{tabular}

* For the present study, we derived average fate factors using national data on emission to surface waters from agricultural land, assuming that the receiving water is a freshwater system. Fate factors are derived in Section 4.1.2.

** The fate factor for marine waters is corrected for the retention factor in freshwater systems (see Section 4.1.1). 
Table 2

Life Cycle Inventory for the offshore production of seaweed.

\begin{tabular}{|c|c|c|}
\hline Phases & Amount & U.M./Mg DW seaweed \\
\hline \multicolumn{3}{|l|}{ Seed line production } \\
\hline \multicolumn{3}{|l|}{ Collection of fertile material } \\
\hline Fuel for car & $2.67 \mathrm{E}-02$ & $\mathrm{~L}$ \\
\hline Tank for seawater & $3.33 \mathrm{E}-04$ & $\mathrm{~kg}$ \\
\hline \multicolumn{3}{|l|}{ Spore release } \\
\hline Plastic jug & $6.67 \mathrm{E}-04$ & $\mathrm{~kg}$ \\
\hline Autoclave & $1.00 \mathrm{E}-01$ & kWh \\
\hline Refrigerator & $3.12 \mathrm{E}-02$ & kWh \\
\hline \multicolumn{3}{|l|}{ Preparation of collectors } \\
\hline Block of Collectors & $2.67 \mathrm{E}-02$ & $\mathrm{~kg}$ \\
\hline Kuralone (1.5 mm) & $7.17 \mathrm{E}-02$ & $\mathrm{~kg}$ \\
\hline Gas & $6.33 \mathrm{E}-03$ & $\mathrm{~kg}$ \\
\hline \multicolumn{3}{|l|}{ Seeding of lines } \\
\hline Spray bottle & $2.67 \mathrm{E}-04$ & $\mathrm{~kg}$ \\
\hline \multicolumn{3}{|l|}{ Nursery phase } \\
\hline Electricity - air pump & $9.80 \mathrm{E}-03$ & kWh \\
\hline Sand & $1.48 \mathrm{E}-02$ & $\mathrm{~kg}$ \\
\hline Mechanical filter $(1-5 \mu \mathrm{m})$ & $3.46 \mathrm{E}-03$ & $\mathrm{~kg}$ \\
\hline UV filter (Bulb) & $6.00 \mathrm{E}-06$ & Piece \\
\hline Electricity - water pump & $2.45 E-03$ & kWh \\
\hline Electricity - sand filter & $1.48 \mathrm{E}-03$ & kWh \\
\hline Electricity - UV filter & $1.10 \mathrm{E}-02$ & kWh \\
\hline F2 medium & $1.60 \mathrm{E}-02$ & $\mathrm{~L}$ \\
\hline \multicolumn{3}{|l|}{ Deployment phase } \\
\hline Screw anchor & $1.80 \mathrm{E}-02$ & $\mathrm{~kg}$ \\
\hline Black buoys & $2.85 \mathrm{E}-01$ & $\mathrm{~kg}$ \\
\hline Thin rope & $1.54 \mathrm{E}-01$ & $\mathrm{~kg}$ \\
\hline Concrete block & $2.67 \mathrm{E}+00$ & $\mathrm{~kg}$ \\
\hline Iron weights & $6.00 \mathrm{E}-01$ & $\mathrm{~kg}$ \\
\hline Cable ties & $1.80 \mathrm{E}-02$ & $\mathrm{~kg}$ \\
\hline Ropes for buoys & $6.00 \mathrm{E}-02$ & $\mathrm{~kg}$ \\
\hline Headline rope (HL) & $6.49 \mathrm{E}-02$ & $\mathrm{~kg}$ \\
\hline Rope for spores (SL) & $2.20 \mathrm{E}-01$ & $\mathrm{~kg}$ \\
\hline Concrete block rope & $1.00 \mathrm{E}-01$ & $\mathrm{~kg}$ \\
\hline Boat use & $4.67 \mathrm{E}-02$ & tkm \\
\hline \multicolumn{3}{|l|}{ Maintenance } \\
\hline Boat use & $4.67 \mathrm{E}-02$ & tkm \\
\hline \multicolumn{3}{|l|}{ Harvest } \\
\hline Industrial bags & $7.14 \mathrm{E}-03$ & $\mathrm{~kg}$ \\
\hline Transport boat & $4.06 \mathrm{E}+02$ & $\mathrm{tkm}$ \\
\hline
\end{tabular}

cycle. The data collected for the seaweed cultivation phase is from onsite measurement at a pilot cultivation site in Limfjorden, Denmark. The data relates to the growth season 2012/2013. Indirect emissions from the production of input materials for the individual steps of the seaweed production phase were weighted according to their lifetime with the aim of quantifying the environmental impact of one seaweed production cycle. The offshore cultivation system at the time of harvest is illustrated in Fig. 2.
At the Limfjorden cultivation site, a small vessel is used to monitor growth, for maintenance and for harvest. However in this paper we assume optimized boat transport based on the Ecoinvent database v.3 (Weidema et al., 2013). Boat transport distances are calculated using the software ArcGIS (ESRI, 2011).

In order to represent Danish seaweed productivity we took an average value of $1.5 \mathrm{Mg}$ DW per hectare, based on two existing seaweed cultivation sites in Denmark: 1) high productivity site: open marine water on the eastern coast of Jutland (Horsens fjord) and 2) low productivity site: closed fjord, Limfjorden.

The high productivity value is based on data provided by Hjarnø Havbrug A/S. The company has a contract to cultivate 100 ha with Saccharina latissima in Horsens fjord. At full operation, Hjarnø deploys 350-400 lines (total area $500 \mathrm{~m} * 2000 \mathrm{~m}$; distance between lines $10 \mathrm{~m}$; headline length $220 \mathrm{~m}$ ). The area can host up to $88 \mathrm{~km}$ of headlines (HL) (220 m * 400 lines). Each HL carries a seeded line (SL) attached in festoons and measuring $1 \mathrm{~km}$ in length (total length SL $400 \mathrm{~km}=400$ lines $/ 1 \mathrm{~km}$ lines) (Fig. 2). The festoons hang down to a depth of about $3 \mathrm{~m}$. Hjarnø Havbrug A/S reports a yearly optimum production of $12 \mathrm{~kg}$ wet weight ( $1.8 \mathrm{~kg} \mathrm{DW}$ ) of seaweed per $\mathrm{m}$ of HL. This means that each line can produce $2.6 \mathrm{Mg}$ of seaweed fresh weight (0.4 Mg DW, 15\% dry matter). In one hectare with up to 5 lines, a production of $13 \mathrm{Mg}$ fresh weight (about $2 \mathrm{Mg} \mathrm{DW}$ ) is expected.

The low productivity value is based on the pilot scale cultivation site in Limfjorden. Average productivity during the growth phase (November to April 2012) was 0.2 Mg DW of Saccharina latissima per seeded line (220 m HL and $1 \mathrm{~km} \mathrm{SL}$ ), corresponding to a productivity of $1 \mathrm{Mg} \mathrm{DW} /$ ha.

Both locations cultivate the brown alga Saccharina latissima (Laminariales, Phaeophyceae) (Linnaeus) (Lane et al., 2006). Biomass composition is based on average composition of Saccharina latissima harvested in Denmark: average nitrogen content 3.25\% and phosphorus content 0.29\% (Manns et al., 2014; Bruhn et al., 2015). It has to be mentioned that seaweed present both seasonal and spatial variations in nutrient composition, as large as 8 times in case of $\mathrm{N}$ (i.e. $0.29-2.32 \%$ of DW) and 5 times in case of P (0.10-0.56\% of DW) (Nielsen et al., 2016).

\subsection{Transport of seaweed}

The seaweed is transported by truck (capacity of $32 \mathrm{Mg}$ ). We considered a transport distance of $30 \mathrm{~km}$, based on the average distance between the coastline and agricultural soil, incineration plants and landfills (DME, 2013).

\subsection{Biofertilizer production and use}

The seaweed is chopped and used directly as a biofertilizer which is spread on the soil instead of mineral fertilizers. According to the Danish

a

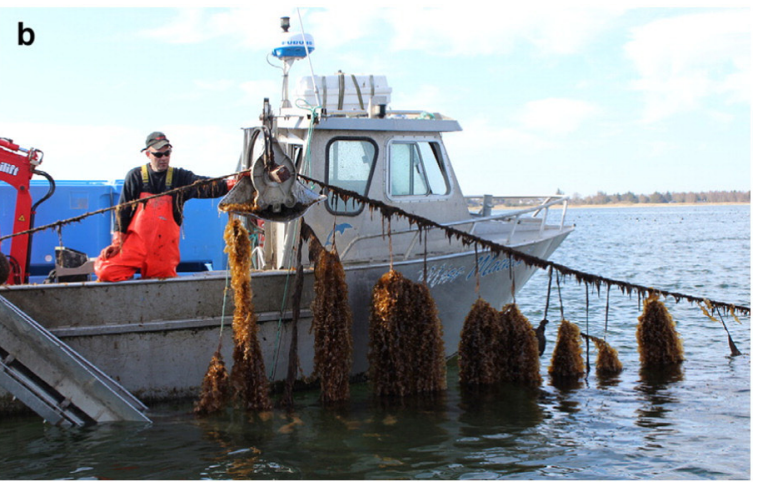

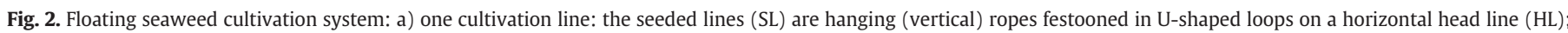
b) cultivation line at harvest time (courtesy of Jens Kjerulf Petersen, Danish Shellfish Center). 
guidelines for fertilization and harmony rules (DAFA, 2013), biofertilizers such as manure have a lower fertilizing value than mineral fertilizers due to their lower bioavailability of $\mathrm{N}$ and $\mathrm{P}$ (Niero et al., 2014; Jensen et al., 2015). Since there are no regulations or data about bioavailability of $N$ and $\mathrm{P}$ in seaweed used as biofertilizer, we assumed the same fertilizing value as manure; i.e. 0.69 for $\mathrm{N}$ and 0.95 for $\mathrm{P}$ (Tambone et al., 2010; Jensen et al., 2015). The indirect emissions avoided by substitution of production of (fossil) mineral fertilizer considered in the LCA are based on the market mix reported in Ecoinvent v3.1 (Weidema et al., 2013). National measures of direct emissions to air during spreading and to water via leaching are provided in Table 1; fate factors are derived in Section 4.1

\subsection{Landfilling}

To estimate the water and air emissions from seaweed disposed of in landfills we used the information contained in the Ecoinvent database (Weidema et al., 2013). A well-managed municipal solid waste landfill was selected as model system based on state of the art technology with base seal, biogas and leachate collection systems, including treatment of leachate in a municipal wastewater treatment plant (Table A.1). Emissions to air of ammonia, dinitrogen monoxide, nitrogen oxides, phosphorus and cyanide originate from short-term two-step percolate treatment and incineration of the residual sludge. The short-term treatment contributes to emissions of ammonium, nitrate, nitrite, nitrogen and phosphate to rivers arising from short-term percolate treatment as well as incineration of the resulting sludge. Emissions of ammonium, nitrate, nitrite, nitrogen and phosphate also come from long-term leachate ( $>100$ years) into groundwater from the landfill and indirectly via incineration of treated leachate sludge. We recalculated emissions of $\mathrm{N}$ - and $\mathrm{P}$ containing substances for seaweed waste type in relation to the $\mathrm{N}$ and $\mathrm{P}$ content of municipal solid waste emissions of $\mathrm{N}$ - and P-containing substances and according to the above treatment processes. In the national emission inventory of GHG and long-distance pollution transport, as in the case of the selected model system, $\mathrm{N}$ emissions to air from waste disposed of in landfills are judged negligible and not included (DCE, 2015). For the present study we used the emissions provided in the Ecoinvent database from short-term treatment of percolate and long-term leachate emissions to derive $\mathrm{N}$ and $\mathrm{P}$ losses associated with landfill disposal of $1 \mathrm{Mg}$ DW of seaweed biomass (Table 1 ).

\subsection{Incineration}

For the incineration scenario, we used the data for incineration of digester sludge based on a technology mix encountered in Switzerland, reported in the Ecoinvent v.3 inventory (Weidema et al., 2013). According to this process, dewatering of sludge and treatment of the resulting liquid is included, in addition to air and water emissions from incineration, influenced by input of auxiliary material for flue gas cleaning. Digester sludge was chosen as representative of combustion emissions of seaweed biomass due to similar characteristics in terms of water content (95\%), biogenic carbon (100\%) and similarity of process, i.e. dewatering. We used the ratio of emissions for incinerated sludge $\mathrm{N}$ and $\mathrm{P}$ content to estimate the emissions from dewatering and incineration of seaweed biowaste (Table A.2). Emissions of ammonium, nitrate and phosphate to water, i.e. river, arise from treatment of dewatering liquid at a wastewater treatment plant. Nitrogen emissions to the subcompartment "river" arise from the incineration process (Table A.2). Emissions to groundwater arise from landfill disposal of slag and other combustion residues, i.e. from solidified fly ash and scrubber sludge.

\section{Life Cycle Impact Assessment methods}

Two different impact assessment methodologies consistent with the goal of the LCA were selected at midpoint: ReCiPe (V1.06) (Goedkoop et al., 2013) and CML-IA (baseline V3.03) (Guinée, 2002), the first of which is recommended by Dong et al. (2013) since it has the most updated model for atmospheric fate and the most consistent framework to calculate characterization factor $(\mathrm{CF})$.

Both methods have a spectrum of impact categories that represent environmental issues of concern. Through a characterization method, the model provides a category indicator which is a quantifiable representation of the impact category (ISO 14044:2006). In order to assign a common unit to the output of the Life Cycle Impact Assessment, it is necessary apply one or more CF describing the causality chain, as detailed in Sections 4.1 to 4.2 (ISO 14044:2006).

ReCiPe distinguishes between the impact of marine and freshwater eutrophication (Goedkoop et al., 2013), measured in units of $\mathrm{N}$ and $\mathrm{P}$ equivalents, respectively, while CML (Guinée, 2002) has a single impact category called eutrophication measured in units of $\mathrm{PO}_{4}^{3-}$.

LCIA models quantify eutrophication of the aquatic environment by calculating nitrogen and phosphorus flows and effects within the system boundaries. The amount of excess nutrients in water contributing to eutrophication can be used as an indicator of the efficiency of a future circular nutrient management system compared to existing management options. This means that the scenario that contributes less to eutrophication has less waste/loss of nutrients and is a more efficient management system. The two LCIA methods selected are based on different characterization models and therefore give different results. In Sections 4.1 to 4.2 , we describe the characterization models underlying ReCiPe and CLM impact categories and in Section 4.1.3, a fourth impact category indicator of P-limited marine eutrophication.

\subsection{ReCiPe}

The ReCiPe method includes two impact category indicators quantifying aquatic eutrophication: freshwater and marine eutrophication. The reasoning behind this differentiation is two-fold: the two systems have different assumed cause-effect relationships and different emission sources, fates and transport.

\subsubsection{The impact category marine eutrophication (ME)}

The impact category Marine Eutrophication (ME) considers $\mathrm{N}$ as the limiting factor for growth in marine systems (Howarth and Marino, 2006) and therefore a marginal increase in nitrogen concentration causes an increase in eutrophication proportional to direct and indirect emissions of nitrogen to marine water. The impact category ME is expressed in $\mathrm{kg}$ of nitrogen equivalents ( $\mathrm{kg} \mathrm{N}$ eq.), meaning that substances containing nitrogen, e.g. ammonia, are converted into nitrogen equivalents according to their stoichiometric composition. The transport of $\mathrm{N}$ via soil, air and freshwater systems is quantified by multiplying the $\mathrm{N}$ content of the molecule by a fate factor that quantifies transport across different environmental compartments, describing the fate of nitrogen from its source to its target system, in this case the marine system. Fate factors are provided in the ReCiPe report (Goedkoop et al., 2013) based on the CARMEN model (Cause effect Relation Model to support Environmental Negotiations) (Klepper et al., 1995).

ReCiPe includes fate factors for the deposition of nitrogen-containing substances (ammonia, cyanide, nitrogen dioxide and nitrogen oxides) from air emissions for all management scenarios. For the MaFe scenario, soil infiltration and leaching to groundwater, respectively, as well as surface runoff to rivers from application of $\mathrm{N}$-containing fertilizer to agricultural soils are also included. The midpoint impact category ME is calculated according to Eq. (1)

Marine eutrophication $=\sum_{i=1}^{n} N C_{i} \cdot m_{i} \cdot F F_{i, j}$

where $N C_{i}$ is the nitrogen content of substance $i, m_{i}$ is the mass of substance $i$, and $F F_{i, j}$ is the fate factor of substance $i$ emitted to marine water from compartment $j$, i.e. soil and air. 
Atmospheric deposition of nitrogen-containing compounds is included by means of a so-called fate factor, which at regional level is 0.11 for ammonia, 0 for cyanide, 0.13 for nitrogen dioxide and 0.13 for nitrogen oxides (Goedkoop et al., 2013).

Nitrogen applied as fertilizer has a CF of $0.073 \mathrm{~kg} \mathrm{~N}$ eq. $/ \mathrm{kg} \mathrm{N}$, while application as manure has a CF of $0.079 \mathrm{~kg} \mathrm{~N}$ eq. $/ \mathrm{kg} \mathrm{N}$. The reason the latter is higher is due to a different mobility of $N$ to air: $21 \%$ for manure and $7 \%$ for fertilizer application (Goedkoop et al., 2013). ReCiPe fate factors for emissions from soil to the marine system due to application of mineral nitrogen fertilizers and manure were compared to fate factors based on national data.

Danish fate factors for $\mathrm{N}$ transport from soil to marine systems are calculated using the ratio of $\mathrm{N}$ application to agricultural soil and agricultural emissions to marine waters according to Eq. (2):

$F F_{A, M W}=\frac{\left(E m i_{A, F}-R_{A}\right)}{\text { Fert }_{A}}$

where $F F_{A, M W}$ is the fate factor for transport of $\mathrm{N}$ from agricultural soil $A$ to marine water $M W, E m i_{A, F}$ are $\mathrm{N}$ emissions from the agricultural sector $A$ to freshwater $F, R_{A}$ is the amount of $\mathrm{N}$ emitted by agriculture that is retained in freshwater systems, i.e. lakes and rivers, and Fert $_{A}$ is the amount of $\mathrm{N}$ fertilizer applied to agricultural soil $A$.

Nitrogen emission from the agricultural sector to freshwater systems, i.e. $E m i_{A, F}$, is reported in national water plans and is $45,395 \mathrm{Mg} \mathrm{N}$ (Table A.3). The amount of $\mathrm{N}$ lost from agriculture, $R_{A}$, retained in Danish freshwater systems is calculated as total retention multiplied by the ratio of $\mathrm{N}$ emission from agriculture to total $\mathrm{N}$ emission (Table A.3) leading to an estimated value of $4728 \mathrm{Mg} \mathrm{N}$ for the fraction of total $\mathrm{N}$ retained in freshwater systems originating from agricultural fertilizer application.

Application of $\mathrm{N}$ decreased from 1992 to 2004 but was relatively stable from 2004 to 2013. Yearly total application of $\mathrm{N}$ to agricultural soil, i.e. Fert $\mathrm{A}_{\mathrm{A}}$, has been quantified as the amount of $\mathrm{N}$ fertilizer applied in $2012 / 2013$, namely $440,000 \mathrm{Mg}$ (Vinther and Olsen, 2014). The resulting fate factor, $F F_{A, M W}$, at national level is 0.092 which is similar to the characterization factor provided by ReCiPe, i.e. 0.073 for mineral fertilizers and 0.079 for manure.

\subsubsection{The impact category freshwater eutrophication (FE)}

As ME assumes $\mathrm{N}$ to be the limiting factor, the FE category assumes that $\mathrm{P}$ is the only limiting factor in freshwater (Schindler et al., 2008), so only substances containing P contribute to FE. The impact category $\mathrm{FE}$ is therefore expressed in $\mathrm{kg}$ of phosphorus equivalent ( $\mathrm{kg} \mathrm{P} \mathrm{eq.).}$ Phosphorous-containing substances emitted to freshwater systems are converted into $\mathrm{kg}$ P eq. by means of CFs. The CFs are a combination of the stoichiometric composition of the substance and the fate in the different compartments, and are calculated according to Eq. (3):

Freshwater eutrophication $=\sum_{i=1}^{n} P C_{i} \cdot m_{i} \cdot F F_{i, j}$

where $P C_{i}$ is the phosphorus content in substance $i, m_{i}$ is the mass of substance $i$, and $F F_{i}$ are the fate factors of substance $i$ transported from soil (compartment $j$ ) to freshwater systems.

For FE there are no CFs for deposition of particulate phosphorus from air to freshwater; i.e. the contribution from emission and deposition of phosphorus from incineration and landfill (Tables A.1 and A.2) is zero.

ReCiPe provides CFs for the contribution to FE from application of mineral fertilizers and manure to agricultural soils; the CFs are $0.053 \mathrm{~kg}$ P eq. $/ \mathrm{kg}$ P for fertilizers and $0.050 \mathrm{~kg}$ P eq. $/ \mathrm{kg}$ P for manure.

Fate factors for emissions from mineral $P$ fertilizers and manure in soil to the freshwater system were compared to fate factors derived from national data. The transport of $P$ from soil to freshwater systems is calculated using the ratio of $\mathrm{P}$ application to agricultural soil to $\mathrm{P}$ emissions to freshwater, according to Eq. (4):

$F F_{A, F}=\frac{\operatorname{Emi}_{A, F}}{\text { Fert }_{A}}$

where $F F_{A, F}$ is the fate factor for transport of $\mathrm{P}$ from agricultural soil $A$ to freshwater $F, E m i_{A, F}$ are $P$ emissions from agricultural soil $A$ to freshwater $F$ and Fert $_{A}$ is the amount of $\mathrm{P}$ fertilizer applied to soil by agricultural sector $A$.

Phosphorus spread alternates between decreasing and stable periods, reaching a stable yearly quantity of P applied since 2010. We therefore used the amount of $P$ fertilizer spread on agricultural soils in 2012-2013 as representative of the yearly amount of $P$ applied to agricultural soil, Fert ${ }_{A}$, i.e. 50,000 Mg per year (Vinther and Olsen, 2014).

Data on P emissions from agriculture to freshwater systems, $E m i_{A, F}$, is not available as the sector is reported together with P emissions from natural background and scattered houses: total P emissions from “total land contributions" being $1301 \mathrm{Mg}$ per year (Table A.4). Thus the resulting fate factor for transport of P from soil to freshwater systems of 0.026 is a conservative estimate, corresponding to loss of $2.6 \%$ of the P fertilizer applied to agricultural soil.

The characterization factor provided by ReCiPe for freshwater eutrophication is 0.053 for mineral fertilizers and 0.05 for manure (Goedkoop et al., 2013). The lower value obtained for our case study compared to the CF value provided in ReCiPe may be explained by extreme downregulation of P application to Danish soils (Vinther and Olsen, 2014; Jensen et al., 2015).

\subsubsection{The impact category P-limited marine eutrophication (P-lim ME)}

In some marine waters, especially where eutrophication has already reached critical levels, $\mathrm{P}$ is the limiting factor for the growth of organisms (Conley et al., 2009). In order to capture the effect of seaweed as an instrument for circular phosphorus management in the LCIA, we therefore add a third category to ReCiPe called marine eutrophication.

Limfjorden water has a salinity between 19\% and 34\% (NA, 2013b), a range characterized as polyhaline ( 18 to $<30 \%$ ) or euhaline (30 to $<40 \%$ ), which exceeds the limit for freshwater $(<0.5 \%$ ) (Directive $2000 / 60 / \mathrm{EC}$ ) and is characterized by $\mathrm{P}$ as the limiting factor for the growth of organisms (Bruhn et al., 2016).

Phosphorus limitation is also found in other areas, e.g. the Baltic Sea (Conley et al., 2002), where reduction of both nitrogen and phosphorus in estuaries and coastal marine ecosystems is recommended to reduce eutrophication (Conley et al., 2009; Howarth and Marino, 2006).

In the impact category P-lim ME, Eq. (2) is modified to include a fate factor quantifying the transport of $\mathrm{P}$ from freshwater to marine systems. In this case fertilizer application, Fert $_{A}$, is $50,000 \mathrm{Mg}$ P, while the emission from the agricultural sector, $E m i_{A, F}$ is approximated by "total land contributions", i.e. $1301 \mathrm{Mg} \mathrm{P} / \mathrm{year}$. The retention of agricultural $\mathrm{P}$ emissions in freshwater systems, $R_{A}$, is estimated by multiplying the retention of total P emission by the ratio of "total Land contributions", i.e. $1301 \mathrm{Mg}$ P, to total emissions to freshwater systems, i.e. $1984 \mathrm{Mg}$ P. The resulting $\mathrm{P}$ emission from the agricultural sector to marine systems, $\mathrm{Emi}_{A, F}-R_{A}$, is $1228 \mathrm{Mg}$ P per year (Table A.4).

We obtained a $F F_{A, F}$ value of 0.025 , meaning that $2.5 \%$ of phosphorus in soil is transferred to marine waters. The calculation is supported by the fact that a short lag phase in the eutrophication effect allows the flow of phosphorus from freshwater to marine waters without considerably affecting the amount of total P. As may be noted, $<6 \%$ of the $\mathrm{P}$ emission is retained in the freshwater system and therefore offshore seaweed cultivation does indeed result in biosorption of land-based P emissions, helping to lower eutrophication.

The impact category P-lim ME allows inclusion of bioextraction of $\mathrm{P}$ (lost via manmade emissions) by offshore cultivation of seaweed, in contrast to the FE impact category, because seaweed is not cultivated in freshwater systems. 


\subsection{The CLM}

The eutrophication category of the CML-IA baseline V3.03 method converts nitrogen and phosphorus speciation into phosphate equivalents ( $\mathrm{PO}_{4}^{3-}$ eq.) according to different CFs (Guinée, 2002). The rationale behind the calculation of CFs is that eutrophication potentials (EPs) (Heijungs et al., 1992) reflect a substance's potential contribution to biomass formation. Eutrophication is a result of the mass of a substance and its eutrophication potential, according to Eq. (5):

Eutrophication $=\sum_{i=1}^{n} E P_{i} \cdot m_{i}$

where $m_{i}(\mathrm{~kg})$ is the mass of substance $i$ released to air, water or soil and $E P_{i}$ is the eutrophication potential of the substance and Eutrophication is expressed in $\mathrm{kg} \mathrm{PO}_{4}^{3-}$ equivalents. The EPs are based on the world average chemical composition of aquatic organisms $\mathrm{C}_{106} \mathrm{H}_{263} \mathrm{O}_{110} \mathrm{~N}_{16} \mathrm{P}$ (Stumm and Morgan, 1981), i.e. $1 \mathrm{~mol}$ of $\mathrm{P}$ has the same eutrophication effect as $16 \mathrm{~mol}$ of $\mathrm{N}$ and $1 \mathrm{~kg}$ of $\mathrm{P}$ has the same effect as $7 \mathrm{~kg}$ of $\mathrm{N}$. Thus the $\mathrm{CF}$ for eutrophication is weighted according to the world average optimal N/P ratio for growth, without any assumptions about the characteristics of the aqueous target system (Heijungs et al., 1992). It also provides $\mathrm{CF}$ for the emission of organic material to water presented as BOD or COD, expressed as $\mathrm{PO}_{4}^{3-}$ equivalents (Dong et al., 2013).

The aim of this approach is to obtain a general, worldwide indicator, independent of local differences, and therefore suitable for the description of eutrophication on a global scale (Heijungs et al., 1992). The methodology does not differentiate between emissions to water via air or from fertilizers applied to soil. As such, an emission of $1 \mathrm{~kg}$ of $\mathrm{N}$ to air and soil would have the same impact on aqueous eutrophication as the emission of $1 \mathrm{~kg}$ of $\mathrm{N}$ to freshwater and marine systems; in other words, the fate factor for transport of $\mathrm{N}$ and $\mathrm{P}$ applied to soil to the aquatic systems is equal to 1 .

Since the focus of our analysis is reduction of eutrophication by means of seaweed cultivation in marine waters, we modified the CML method, using FF for the transport of $\mathrm{N}$ and $\mathrm{P}$ from soil to marine waters according to Eq. (6):

Eutrophication $=\sum_{i=1}^{n} E P_{i} \cdot m_{i} \cdot F F_{i, j}$

where $E P_{i}$ is the eutrophication potential of substance $i, m_{i}$ is the mass of substance $i$ released to air, water or soil and $\mathrm{FF}_{i}$ is the fate factor of substance $i$ emitted to marine water from compartment $j$, i.e. soil. The calculation of FF is described in Sections 4.1.1 and 4.1.3, and is 0.088 for nitrogen and 0.025 for phosphorus. The impact of the emissions to air inventoried in the MaFe, landfill and incineration management scenarios are calculated according to Eq. (5), i.e. excluding FF for deposition from air to water. Cyanide emissions do not have a characterization factor in this impact category and therefore do not contribute to impact category eutrophication calculated by the CLM method.

\section{Life Cycle Impact Assessment - results and discussion}

The results of LCIA performed on three seaweed management scenarios (Fig. 1) are shown in Table 3 and refer to the functional unit of $1 \mathrm{Mg}$ DW of seaweed. A net negative result means that eutrophication impact is reduced compared to a situation without seaweed cultivation, harvest and management according to the options in Fig. 1. The MaFe management scenario performed best for the impact category marine eutrophication (ReCiPe), eutrophication (CML) and P-limited marine eutrophication. For freshwater eutrophication (ReCiPe), management by incineration was the best option (Table 3 ).

A more detailed picture of how individual processes contribute to the overall result is provided in Fig. 3 and explained in Sections 5.1 to 5.4.

\subsection{Marine eutrophication - ReCiPe}

All three seaweed management scenarios showed that seaweed production had a beneficial effect on marine eutrophication. Of the three, MaFe performed best with a net reduction of $-32.29 \mathrm{~kg} \mathrm{~N}$ eq. (Table 3 and Fig. 3a), followed by the incineration scenario with $-29.24 \mathrm{~kg} \mathrm{~N}$ eq., and the landfilling scenario with a total of $-3.05 \mathrm{~kg}$ N eq. (Table 3).

The main process contributing to the reduction of eutrophication (negative values) for all three management scenarios was bioextraction of $\mathrm{N}$ (dark red bar, Fig. 3a) quantified as $-32.45 \mathrm{~kg} \mathrm{~N}$ eq. which is the amount of nitrogen that the seaweed extracts from marine water during its growth.

The highest emission (positive value) occurred for the landfill scenario, where the total (direct and indirect) emission to water was almost $90 \%$ of the bioextracted N. Nitrogen emissions to water from the MaFe and the Incineration scenarios were comparable and 7-10\% of that from landfill and associated percolate treatment processes (Table A.1). Nitrogen leaching from soil due to biofertilizer application and emission to water due to incineration were $2.1 \mathrm{~kg} \mathrm{~N}$ eq. and $2.9 \mathrm{~kg} \mathrm{~N}$ eq., respectively. Emissions from seaweed-based biofertilizer application were counterbalanced by a reduction in emissions due to substitution of mineral $\mathrm{N}$ fertilizers. A similar contribution to eutrophication reduction from substitution of fossil electricity production, i.e. Danish electricity mix, occurred in the Incineration scenario; the latter was evaluated as a reduction of -0.08 compared to $-2.1 \mathrm{~kg} \mathrm{~N}$ eq. in the MaFe scenario. As a result, the net impact of the MaFe scenario was lower than that of the incineration scenario; i.e. the MaFe management scenario performs best.

Table 3

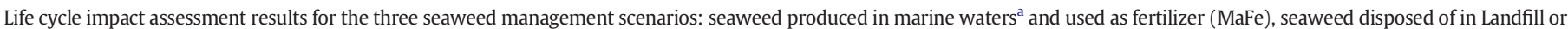
Incinerated. The results refer to a functional unit of $1 \mathrm{Mg}$ dry weight of seaweed.

\begin{tabular}{|c|c|c|c|c|c|}
\hline \multirow[t]{2}{*}{ Methodology } & \multirow[t]{2}{*}{ Impact category } & \multicolumn{3}{|c|}{ Seaweed management scenario } & \multirow[t]{2}{*}{ U.M. } \\
\hline & & MaFe & Landfilling & Incineration & \\
\hline ReCiPe & Marine Eutrophication (MA) ${ }^{\mathrm{b}}$ & -32.29 & -3.05 & -29.24 & kg N eq./Mg DW \\
\hline ReCiPe & Freshwater Eutrophication $(\mathrm{FE})^{\mathrm{c}}$ & 0.13 & 0.14 & -0.08 & kg P eq./Mg DW \\
\hline ReCiPe & P-Limited Marine Eutrophication ${ }^{\mathrm{d}}$ & -2.79 & -2.78 & -2.99 & kg P eq./Mg DW \\
\hline CML & Eutrophication $^{\mathrm{e}}$ & -16.58 & -8.50 & -14.90 & kg PO43- eq./Mg DW \\
\hline
\end{tabular}

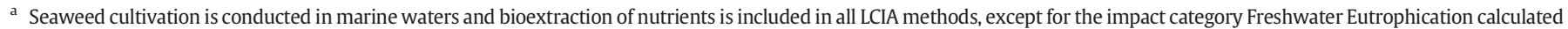
by the ReCiPe method.

b To increase the consistency of the LCIA results, we applied a national fate factor for loss of N to marine systems from fertilizer use on agricultural soil, corrected for retention in freshwater systems (Section 4.1.1).

c The national fate factor for transfer of P from soil to freshwater was applied (see section 4.1.2) and seaweed bioextraction of P was excluded as seaweed cultivation is conducted in marine waters.

d P-limied Marine eutrophication considers the eutrophication impact on P-limited marine waters, as in the case of Limfjorden. We use the available CFs for the eutrophication potential (Section 4.1.2, Eq. (3)) multiplied by the fate factors for transfer of $\mathrm{N}$ and $\mathrm{P}$ from soil to marine waters as provided in Section 4.1.3.

e National fate factors are introduced into the modelling of aquatic eutrophication to adjust for the fate of $\mathrm{N}$ and $\mathrm{P}$ (see Eq. (6) in Section 4.2). 
a) Marine eutrophication - ReCiPe

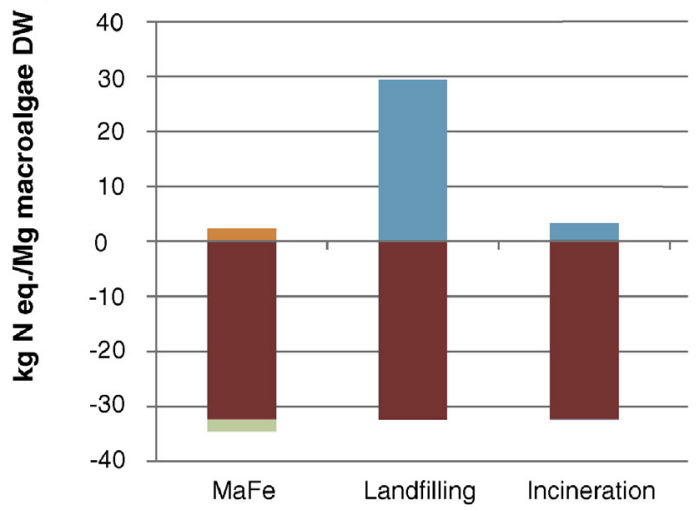

c) Marine eutrophication - P Limited - ReCiPe

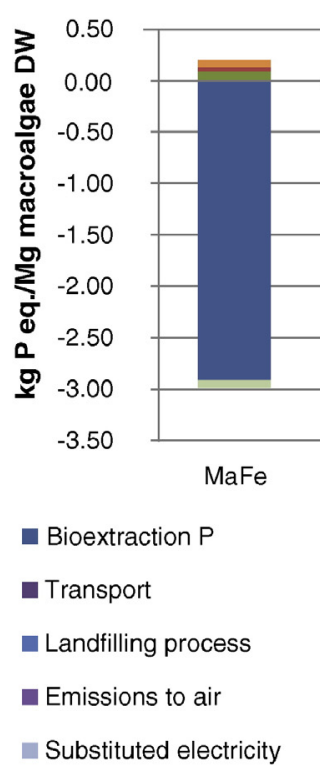

b) Freshwater eutrophication - ReCiPe

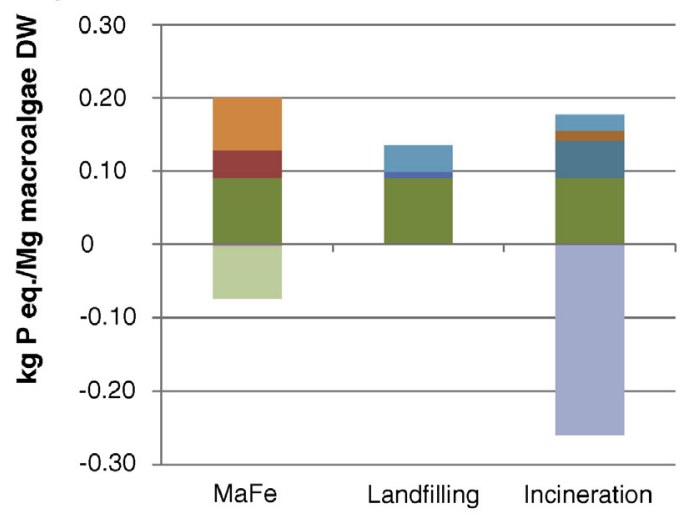

d) Eutrophication - CML

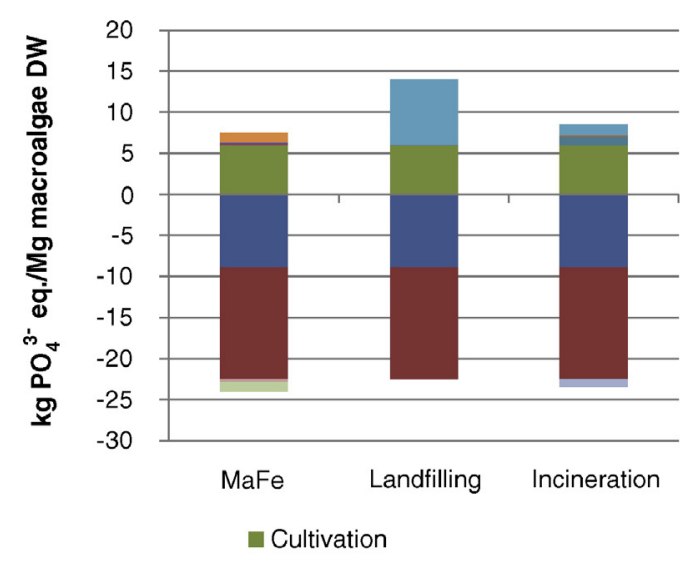

Incineration process

- Spreading

Biofertilizer to soil

- Substituted min. fertilizers use

Fig. 3. Life Cycle Impact Assessment results.

\subsection{Freshwater eutrophication - ReCiPe}

The results for freshwater eutrophication showed that only the incineration scenario has a net negative result, i.e. $-0.08 \mathrm{~kg}$ P eq., and is therefore the only management scenario that contributes to reduction of eutrophication in P-limited freshwater systems (Fig. 3b, Table 3). The MaFe and Landfill management scenarios aggravated eutrophication, increasing excess phosphorous in freshwater systems by $0.13 \mathrm{~kg} \mathrm{P}$ eq. and $0.14 \mathrm{~kg}$ P eq., respectively (Table 3 ).

In the ReCiPe calculation of freshwater eutrophication, the bioextraction potential of seaweed has no beneficial impact as the cultivation occurs in marine waters (see Section 4.1). Actually, the cultivation process contributes with a positive value of $0.09 \mathrm{~kg} P$ eq. in all three management scenarios. $P$ emissions from input materials used for production of plastic ropes, on which the seaweed grows (Fig. 2), account for $92 \%$ of the eutrophication impact from the cultivation phase.

Phosphorus emissions to water were lower for the incineration than for the landfill scenario: 0.02 versus $0.04 \mathrm{~kg} P$ eq.

Phosphorus emission from soil to freshwater due to biofertilizer application has an impact of $0.07 \mathrm{~kg}$ P eq. which however is counterbalanced by emissions avoided by substitution of mineral $P$ fertilizer production and use of $0.07 \mathrm{~kg}$ P eq. The contribution to freshwater eutrophication of the production phase of mineral P fertilizers is insignificant at $0.2 \%$ of the emissions originating from the use phase.

In the incineration management scenario, avoided impact due to substitution of type of energy production has a significant effect on the final result. This is caused by a reduction in $\mathrm{P}$ emissions from the mining of coal used in heating and power plants. Energy consumption for dewatering seaweed waste, i.e. water reduction phase, contributes with a positive value of $0.05 \mathrm{~kg}$ P eq. However, substitution of fossil fuelled energy production with energy from incineration of seaweed reduces eutrophication level by $0.26 \mathrm{~kg} \mathrm{P}$ eq.

From the MaFe management scenario, we can see that the impact of biofertilizer application (Fig. 3b, orange bar) is balanced by substitution of mineral fertilizers. As mentioned in Section 3.3, the fertilizing value of seaweed biofertilizer is 95\%; i.e. $1 \mathrm{~kg}$ of biofertilizer P substitutes $0.95 \mathrm{~kg}$ of mineral P. However, when the sum of indirect P emissions from the cultivation, chopping and spreading of biofertilizer is considered it exceeds the emissions avoided by substitution of mineral P fertilizer.

Lastly, it is important to emphasize that P emissions from cultivation and chopping come from the production of plastics used for the seaweed cultivation system, while part of the energy consumed to chop the algae is coal-based (the coal mining process). The same is true for energy consumed to treat percolate of the Landfill and incineration scenarios, respectively. 
Table 4

River basin and marine water body surface area of the 21 Danish river basin districts analyzed.

\begin{tabular}{llrr}
\hline ID & Location & $\begin{array}{c}\text { River basin } \\
\left(\mathrm{km}^{2}\right)\end{array}$ & $\begin{array}{c}\text { Marine water } \\
\text { body }\left(\mathrm{km}^{2}\right)\end{array}$ \\
\hline 1.1 & Nordlige Kattegat and Skagerrak & 2659 & 7927 \\
1.2 & Limfjorden & 7598 & 3430 \\
1.3 & Mariager Fjord & 574 & 46 \\
1.4 & Nissum Fjord & 1632 & 65 \\
1.5 & Randers Fjord & 3257 & 26 \\
1.6 & Djursland & 1011 & 3972 \\
1.7 & Aarhus Bugt & 775 & 1679 \\
1.8 & Ringkøbing Fjord & 3494 & 2892 \\
1.9 & Horsens Fjord & 794 & 460 \\
1.10 & Vadehavet & 4429 & 2374 \\
1.11 & Lillebælt/Jylland & 2373 & 1221 \\
1.12 & Lillebælt/Fyn & 990 & 1439 \\
1.13 & Odense Fjord & 1193 & 457 \\
1.14 & Storebælt & 538 & 1418 \\
1.15 & Det Sydfynske Øhav & 765 & 830 \\
2.1 & Kalundborg & 983 & 2232 \\
2.2 & Isefjord and Roskilde Fjord & 1943 & 439 \\
2.3 & Øresund & 816 & 1920 \\
2.4 & Køge Bugt & 995 & 742 \\
2.5 & Smålandsfarvadet & 3440 & 2175 \\
2.6 & Østersøen & 1088 & 3665 \\
& Total & 41,348 & 39,410 \\
\hline
\end{tabular}

In conclusion, substitution of indirect $\mathrm{P}$ emissions originating from the use of coal in the Danish energy system is the main reason why the Incineration scenario had the best performance, but freshwater eutrophication is not decreasing in Danish freshwater systems. Likewise, eutrophication from cultivation (green bars) is not impacting Danish freshwater systems, but rather local freshwater systems at the site of raw material production for construction of the artificial seaweed growth substrate. If we exclude indirect emissions, i.e. P emissions to freshwater systems in other parts of the world, we obtain net P emissions for the three management scenarios of $0.04 \mathrm{~kg} P$ eq. (MaFe and the Landfill management scenarios) and $-0.08 \mathrm{~kg} P$ eq. (Landfill management scenario).

\subsection{P-limited marine eutrophication - ReCiPe}

The category P-limited marine eutrophication described in Section 4.1.3 shows that in this case all the scenarios have a negative impact, meaning an improvement compared to a situation without seaweed cultivation. Among the three management scenarios, incineration showed the best performance quantified as $-2.99 \mathrm{~kg} P$ eq., followed by $\mathrm{MaFe}$ with $-2.79 \mathrm{~kg} \mathrm{P}$ eq. and landfilling with $-2.78 \mathrm{~kg} \mathrm{P}$ eq. (Table 3). Bioextraction of $P$ during seaweed growth is the main process that reduces the impact of eutrophication (Fig. 3c). The inclusion of bioextraction significantly affects the result in all scenarios, reducing impacts by $-2.91 \mathrm{~kg} P$ eq. For P-limited waters and P bioextraction in general, this process exceeds the emissions from all three management scenarios to an extent that makes loss of $\mathrm{P}$ from process emission $<5 \%$ in all scenarios.

In conclusion, the impact category P-limited ME highlights the importance of seaweed cultivation as an instrument for circular nutrient management.

\subsection{Eutrophication CML}

In the eutrophication impact category calculated according the CML method, we see a negative result for the three seaweed management scenarios, i.e. lower eutrophication is obtained with respect to a situation without offshore seaweed cultivation (Table 3 and Fig. 3d). The best performing management scenario is the MaFe scenario, which a

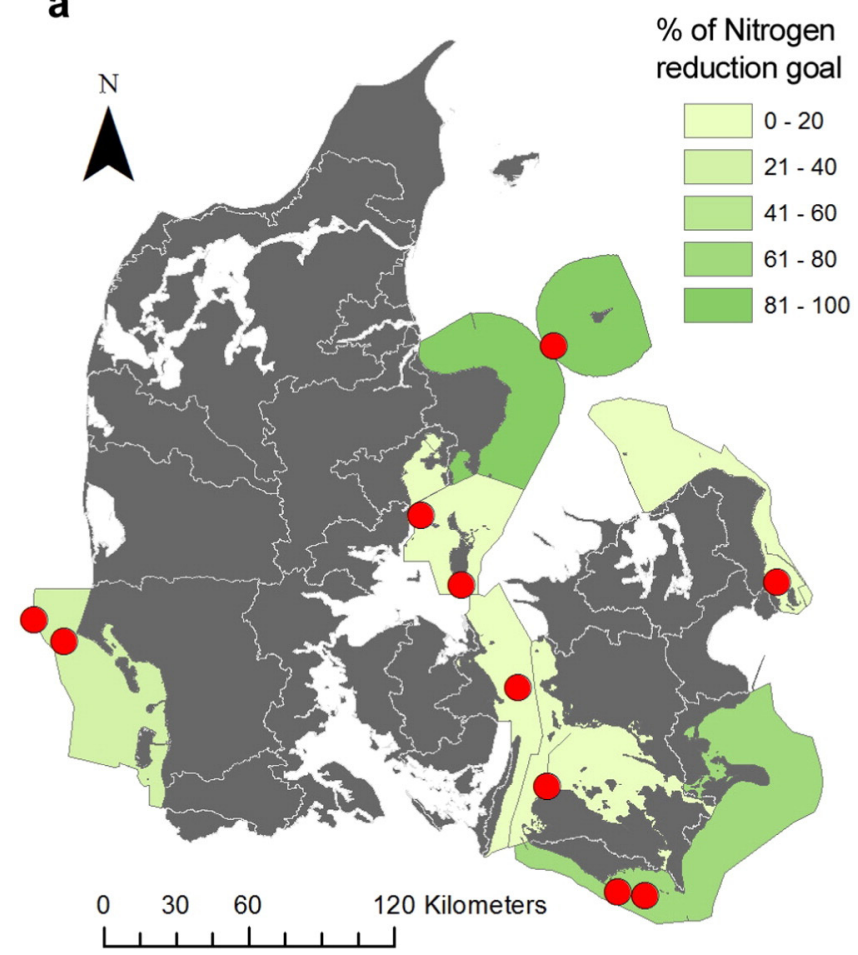

b

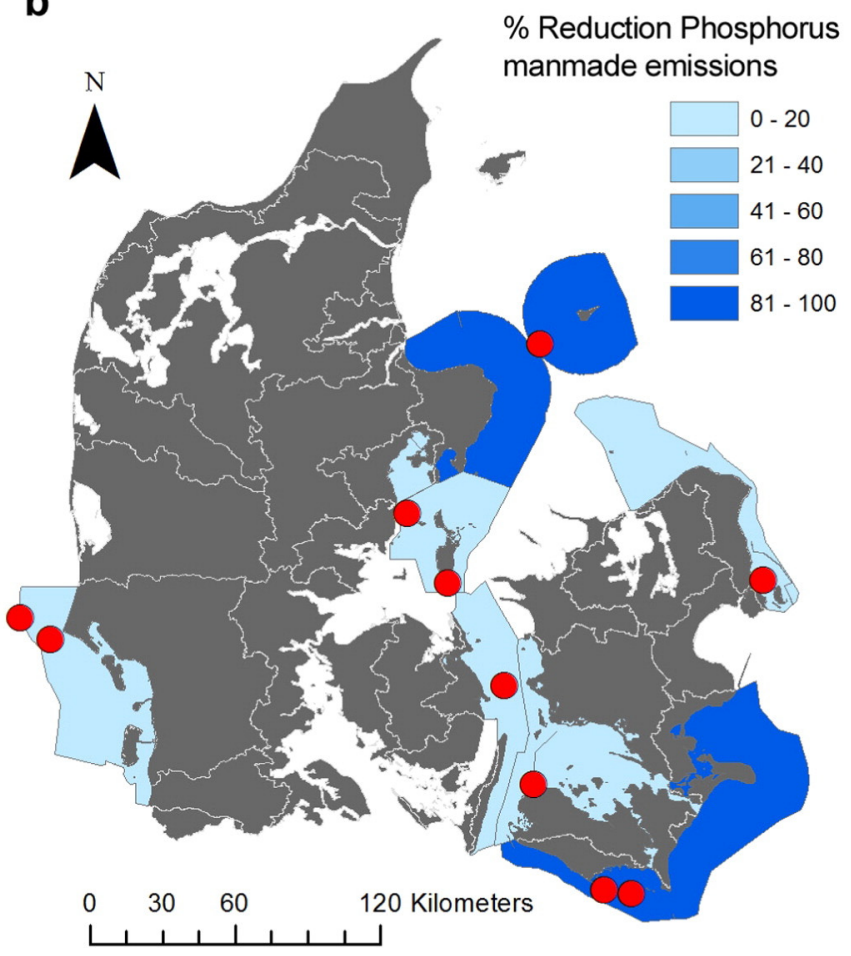

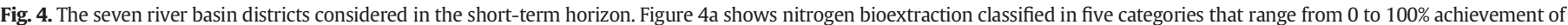

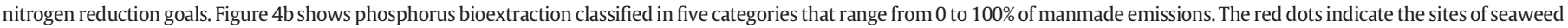

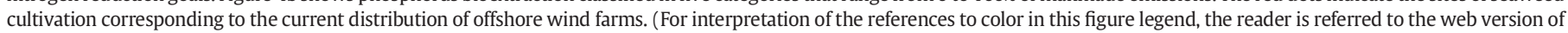
this article.) 
Table 5

Results of short-term horizon of seaweed cultivation in Denmark ${ }^{1}$.

\begin{tabular}{|c|c|c|c|c|c|c|c|c|c|c|c|}
\hline & $\begin{array}{l}\text { River } \\
\text { basin } \\
\text { district }\end{array}$ & $\begin{array}{l}\text { Cultivation } \\
\text { area }\left(\mathrm{km}^{2}\right)\end{array}$ & $\begin{array}{l}\mathrm{N} \text { manmade } \\
\text { emissions } \\
(\mathrm{Mg})\end{array}$ & $\begin{array}{l}\text { P net } \\
\text { emissions } \\
(\mathrm{Mg})\end{array}$ & $\begin{array}{l}\text { Seaweed } \\
\text { production } \\
(\text { Mg DW) }\end{array}$ & $\begin{array}{l}\mathrm{N} \\
\text { Bioextra. } \\
(\mathrm{Mg})\end{array}$ & $\begin{array}{l}\text { P } \\
\text { Bioextra. } \\
(\mathrm{Mg})\end{array}$ & $\begin{array}{l}\mathrm{N} \text { reduction } \\
\text { goals }(\mathrm{Mg})\end{array}$ & $\begin{array}{l}\text { Bioextra./N } \\
\text { manmade } \\
\text { emission }\end{array}$ & $\begin{array}{l}\text { Bioextra./N } \\
\text { Reduction } \\
\text { goal }\end{array}$ & $\begin{array}{l}\text { Bioextra./P } \\
\text { net } \\
\text { emissions }\end{array}$ \\
\hline Anholt & 1,6 & 88 & 912 & 24 & 13,200 & 428 & 39 & 112 & $47 \%$ & $>100 \%$ & $>100 \%$ \\
\hline Samsø + Tunø Knob & 1,7 & 0.3 & 562 & 29 & 48 & 2 & 0.1 & 214 & $0.3 \%$ & $0.7 \%$ & $0.5 \%$ \\
\hline Horns Rev II + Horns Rev I & 1,10 & 56 & 6349 & 246 & 8400 & 273 & 25 & 1187 & $4 \%$ & $23 \%$ & $10 \%$ \\
\hline Sprogø & 1,14 & 0.003 & 539 & 23 & 0.4 & 0.01 & 0.001 & 116 & $0.002 \%$ & $0.01 \%$ & $0.01 \%$ \\
\hline Middelgrunden & 2,3 & 0.003 & 906 & 149 & 0.5 & 0.02 & 0.001 & 31 & $0.002 \%$ & $0.05 \%$ & $0.001 \%$ \\
\hline Vindeby & 2,5 & 3 & 4182 & 126 & 450 & 15 & 1 & 2099 & $0.3 \%$ & $0.7 \%$ & $1 \%$ \\
\hline Rødsand II + Nysted (Rødsand I) & 2,6 & 61 & 1503 & 30 & 9150 & 297 & 27 & 379 & $20 \%$ & $78 \%$ & $89 \%$ \\
\hline Total & & 208 & 14,953 & 627 & 31,249 & 1014 & 91 & 4137 & $7 \%$ & $25 \%$ & $15 \%$ \\
\hline
\end{tabular}

1 The columns indicate: 1 . the name of the current offshore wind farm, 2 . the corresponding code of the river basin district, 3 . water surface area occupied by seaweed cultivation and

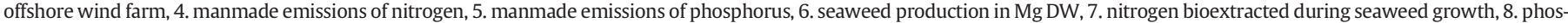

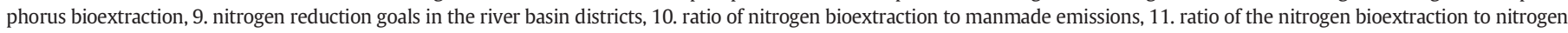
reduction goals, 12 . ratio of phosphorus bioextraction to net emissions.

has a net reduction quantified as $-16.58 \mathrm{~kg} \mathrm{PO}_{4}^{3-}$ eq. Significant emissions to water in the landfill scenario affect its final performance, making it the worst of the three.

In this impact category, both nitrogen and phosphorus are accounted and converted into $\mathrm{PO}_{4}^{3-}$ eq., so it is possible to see the effect of bioextraction of $\mathrm{N}$ and $\mathrm{P}$ on eutrophication using this impact category indicator. Overall, bioextraction is the most significant process in all the management scenarios and has the potential to significantly reduce eutrophication in Danish waters through implementing offshore seaweed production.

Concerning substituted products, the Danish electricity mix has an impact quantified as $0.9 \mathrm{~kg} \mathrm{PO}_{4}^{3-}$ eq. while mineral fertilizer (production and use) decreases impact in the MaFe scenario by $1.5 \mathrm{~kg} \mathrm{PO}_{4}^{3-}$ eq. As mentioned above, the emissions occur at the site of coal mining and do not impact the local trophic status of Danish coastal waters.
Compared to ME and P-limited ME, the cultivation phase has a significant impact, quantified as $6.0 \mathrm{~kg} \mathrm{PO}_{4}^{3-}$ eq. The impact is mainly affected by the manufacture of iron weights for the cultivation line. The different CF used in CML highlights another aspect of the cultivation phase compared to ReCiPe. Still, the emissions are not local, but contribute to eutrophication at the input site of material production.

In general, seaweed cultivation has a beneficial effect on marine eutrophication in all three impact categories except FE, thanks to their ability to subtract excess nutrients from marine water. The results are significant at local scale, in this case Danish marine waters, since the most significant contribution directly affecting nutrient concentrations in marine waters is bioextraction of manmade emissions to water. The landfill option was the least effective with regard to nutrient loss, while incineration performed better than landfilling but worse than MaFe, due to substitution of mineral fertilizer. Lastly, the impact of
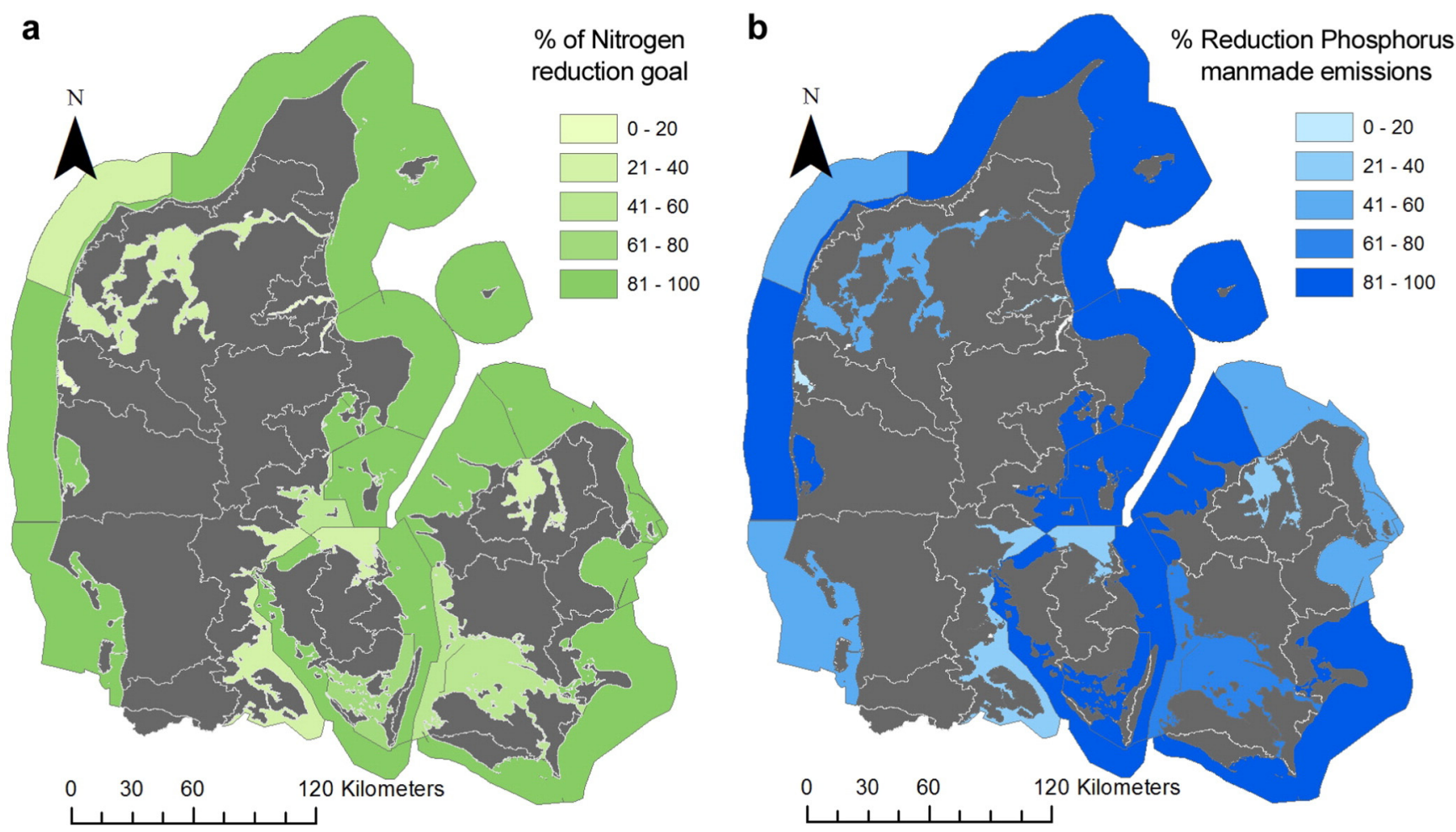

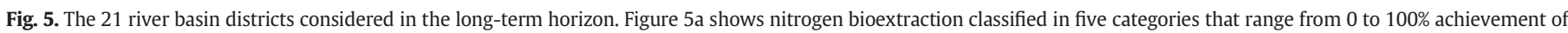
nitrogen reduction goals. Figure $5 \mathrm{~b}$ shows phosphorus bioextraction classified in five categories that range from 0 to $100 \%$ of manmade emissions. 
material production for the cultivation system is negligible compared to the direct beneficial effects of seaweed production and management.

\section{Efficacy of seaweed as nutrient management tool}

In order to understand to what extent it is possible to counterbalance yearly manmade emissions by seaweed bioextraction, we complemented LCA with a comparison between nutrient emission supply to Danish marine waters and the bioextraction potential of seaweed biomass as a function of: 1) local environmental parameters influencing growth (Seghetta et al., 2016c; Bruhn et al., 2016); 2) size of cultivation area.

A conceptual framework model for future coastal and marine nutrient management is now briefly described. Sustainable growth of future blue business, offshore seaweed production in the present case, is a function of the overall mass balance of the system that can be under three different conditions:

\section{Nutrient emission supply $>$ nutrients bioextracted}

In this case the nutrient supply exceeds seaweed capacity to absorb it and nutrient concentrations in the hydrosphere therefore increase in the long term;

\section{Nutrient emission supply $<$ nutrients bioextracted}

In this case seaweed growth absorbs more nutrients than provided by human activities (manmade emissions) each year. In the long term, nutrient concentrations in the hydrosphere decline and water quality improves;

\section{Nutrient emission supply $=$ nutrients bioextracted}

In this case there is a balance between nutrients bioextracted by seaweed and nutrients emitted by the lithosphere and human activities. The balance does not change nutrient concentrations in the water and water quality does not change.

The cultivation and harvest of blue biomass can be expected to improve the health of the aquatic system under condition 1 by mitigating eutrophication. However, for "blue" undertakings to be environmentally sustainable, they must not transform into the situation illustrated by condition 2, while optimum expansion of the business is represented by condition 3 where a "non-eutrophic" environment is preserved, the blue technology balancing nutrient emissions from land-based human activities.

Three time horizons are compared: the present, short-term and long-term. Present maximum cultivation of seaweed in Denmark consists of a 3 ha pilot-scale production site in Limfjorden and a 100 ha industrial-scale cultivation area in Horsens fjord. The productivity of the two sites is 100 and $200 \mathrm{Mg} \mathrm{DW}$ seaweed $/ \mathrm{km}^{2}$, respectively, as described in Section 3.1.

The short-term horizon is based on the assumption that seaweed production will grow rapidly in the next 20 years (BIM, 2014; Skjermo et al., 2014; Christensen et al., 2013). Short-term industrial-scale seaweed cultivation in Denmark is expected to develop as has offshore wind farming, which went from eleven $450 \mathrm{~kW}$ turbines in 1991 to a current installed power of $1.3 \mathrm{GW}$. In 24 years, the offshore wind farm industry has gradually occupied about $208 \mathrm{~km}^{2}$. We assume that in 20 years the same or an equivalent area could be used for seaweed cultivation. Integration of seaweed cultivation and offshore wind farming is technically possible but has to overcome social perception barriers (Reith et al., 2005, 2012). Utilizing an average productivity of 1.5 Mg DW/ha we can potentially grow 31,249 Mg DW (208,329 Mg fresh weight (FW)) of seaweed.

The long-term horizon assumes a development in offshore seaweed cultivation to cover $10 \%$ of marine surface area in 50 years; the figure of $10 \%$ comes from N'Yeurt et al. (2012) who report that a seaweed ocean forest covering $9 \%$ of the world's ocean surface could produce enough biomethane to meet current fossil fuel energy demand.

\subsection{Nutrient emission supply to Danish river basin districts}

In line with the European Water Framework Directive (Directive nr. 2000/60/EF of 23 October 2000), Danish land and the sea around Jutland peninsula, Fyn Island and Zealand Island have been divided into 21 "river basin districts". A "river basin district" means the area of land and sea, made up of one or more neighbouring river basins together with their associated groundwaters and coastal water [...] (Directive nr. 2000/60/EF of 23 October 2000). A river basin is the catchment area of all surface run-off, streams, rivers and lakes into the sea at a single river mouth, estuary or delta. Coastal water means surface water on the landward side of a line, every point of which is at a distance of one nautical mile on the seaward side from the nearest point of the baseline from which the breadth of territorial water is measured (Directive nr. 2000/60/EF of 23 October 2000). For the sake of simplicity, we call "river basin" the area of land included in a river basin district and "marine water body" the sum of coastal and marine water within 12 nautical miles of the coast included in a river basin district.

Reported monitoring data on emissions of total nitrogen and total phosphorus from river basins to marine water body were collected and reported in Tables A.1 and A.2. Nitrogen emissions have been grouped according to eight source categories: natural background, agriculture, waste water treatment plants (WWTP), rainwater, industries, scattered houses, fish farms and aquaculture. Phosphorus emissions have been grouped according to six source categories: open land contribution (this category groups together natural background, agriculture and scattered houses due to uncertainty in the allocation of emissions), waste water treatment plants, rainwater, industry, fish farms and aquaculture. For nitrogen and phosphorus, nutrient retention in freshwater systems (streams and lakes) is also included. We also calculated net emissions of nitrogen and phosphorus, i.e. manmade emissions of $\mathrm{N}$ (P) in marine water bodies as the sum of the eight source categories (six for phosphorus), subtracting retention and natural background. The retention of agricultural emissions of $\mathrm{N}$ varies in the different districts between $0.2 \%$ and $45.6 \%$; retention of P from total land contributions varies between $0.2 \%$ and $24.7 \%$.

The latest available data from 2013 reports was used (emissions monitored and reported in 2012; NA, 2013a-u). The dataset on the 21 river basin districts is the highest resolution input data available for quantifying the nutrient emission supply (Tables A.1, A.2).

In some of the river basin districts, a clear geographical definition of the boundaries of the marine water body is missing from the NA (2013a-u) reports. Surface areas of the missing marine water bodies were addressed using online maps from the Danish Ministry of Environment (http://miljoegis.mim.dk/). When necessary, we aggregated subareas into a complete marine water body according to the information contained in the NA (2013a-u) reports. For sub-areas not included in the reports we applied a proximity criterion, i.e. the sub-area was aggregated with the adjacent group closest to the river basin. The resulting areas of the marine water bodies and river basins are shown in Table 4.

\subsection{The present}

In the present situation, a total of 103 ha of marine water is occupied by seaweed cultivation. The first cultivation site is in Limfjorden and the second in Horsens Fjord. Considering the real productivity and cultivation size in Limfjorden (100 Mg DW/ $\mathrm{km}^{2}$ and $0.03 \mathrm{~km}^{2}$ respectively) the bioextraction capacity is $0.1 \mathrm{Mg}$ of nitrogen and $0.01 \mathrm{Mg}$ of phosphorus. Compared to yearly manmade emissions to the water body, bioextraction is negligible at $0.001 \%$ and $0.003 \%$ for $\mathrm{N}$ and $\mathrm{P}$, respectively (Tables A.1 and A.2). Limfjorden is an extreme case of yearly nitrogen emission supply (load). It would be necessary to use $79 \%$ of the water surface area to counterbalance total yearly emission of N, and 33\% in the case of P emissions. In this situation, seaweed cannot be the only solution for remediation of eutrophication, but can still be integrated with 
other strategies on land, such as wetland improvement (Hasler et al., 2012).

The cultivation site in Horsens Fjord seems to have more favourable environmental conditions for seaweed growth, resulting in a production of $200 \mathrm{Mg} \mathrm{DW} / \mathrm{km}^{2}$. The cultivation site $\left(1 \mathrm{~km}^{2}\right)$ currently bioextracts $1 \%$ of the yearly manmade nitrogen and $3 \%$ of the net phosphorus emission supply, respectively. To meet the nitrogen reduction goals for Horsens Fjord (Jacobsen, 2012) it is necessary to create 57 more cultivation sites of $1 \mathrm{~km}^{2}$ (covering $12 \%$ of the total marine water body surface). For phosphorus, $36 \mathrm{~km}^{2}$ would be sufficient, which is $8 \%$ of the total marine water body surface area.

\subsection{The short-term horizon}

The short-term horizon corresponds to the current location of 10 offshore wind farms (Fig. 4) situated in seven different marine water bodies, according to the description in Section 6.1. Overall, 14,953 Mg of $\mathrm{N}$ and $501 \mathrm{Mg}$ of $\mathrm{P}$ from manmade activities are emitted per year in the selected area. Agriculture is the main source of $\mathrm{N}$ emissions to marine water bodies, followed by the natural background (Table A.1). Since the latter is the natural emission that would occur in a relatively undisturbed environment, it is not counted among total manmade emissions.

Concerning nitrogen, seaweed cultivations are not able to counterbalance $100 \%$ of manmade emissions. Total bioextraction is only $7 \%$ of emissions (ranging between $5 \%$ and $9 \%$ in cases of low and high productivity). River basin district no. 1.6 achieves the best performance with a bioextraction of $47 \%$ of manmade emissions and condition 2 described in Section 6. In the same district, it is also possible to reach the target for $\mathrm{N}$ reduction, i.e. $112 \mathrm{Mg} \mathrm{N}$, by seaweed cultivation alone. A significant contribution is also obtained in districts nos. 2.6 and 1.10, where $78 \%$ and $23 \%$ of the $\mathrm{N}$ reduction goal is achieved, respectively (Table 5 and Fig. 4a) (in cases of high productivity these could increase to $100 \%$ and $31 \%$ ). In the other districts, the contribution is negligible because the cultivated areas are small $\left(<3 \mathrm{~km}^{2}\right)$ (Table 5).

Concerning phosphorus, seaweed can counterbalance manmade emissions in district no. 1.6, showing condition 1 described in Section 6. Seaweed has a significant positive impact on phosphorus bioextraction in district no. 2.6 (89\% of emissions) and in district no. 1.10 (10\% of emissions) (Table 5 and Fig. $4 \mathrm{~b}$ ), which could increase up to $100 \%$ and $13 \%$ in cases of high productivity. Overall, total bioextracted $\mathrm{P}$ in Denmark reaches $91 \mathrm{Mg}$, which is $25 \%$ of total P emissions in the seven river basin districts considered.

As a preliminary conclusion we can say that nitrogen and phosphorus supply are not a constraint for the seaweed cultivation business. As we have already seen in the LCA assessment, bioextraction of P and N, subsequently used as fertilizer, can reduce the depletion of mineral fertilizers. Considering total bioextraction at national level and comparing it with mineral fertilizer sales, we see that production of 31,249 Mg DW of seaweed provides $1014 \mathrm{Mg}$ of $\mathrm{N}$ and $91 \mathrm{Mg}$ of $\mathrm{P}$ for agriculture. On the basis of nutrient bioavailability, they can displace $700 \mathrm{Mg}$ of mineral $\mathrm{N}$ and $87 \mathrm{Mg}$ of mineral $\mathrm{P}$. This results in a decrease in $\mathrm{N}$ and $\mathrm{P}$ sales in Denmark (DAFA, 2012) of $-0.4 \%$ and $-0.8 \%$, respectively. At national level, the short-term horizon does not provide enough biomass to affect the global market of mineral fertilizer.

\subsection{The long-term horizon}

The cultivation of seaweed in the 21 districts creates different mass balance conditions, as presented in Section 6. When the average production of $150 \mathrm{Mg} \mathrm{DW} / \mathrm{km}^{2}$ is considered, seven districts are in condition 2, i.e. bioextracted nutrients exceed total nutrient supply (Tables A.5 and A.6). All the other districts are in condition 1. However, considering the reduction goals set by the Danish environmental agency (Jacobsen, 2012), seaweed proves to be an effective measure in 10 out of 21 districts (Fig. 5a). The Danish government strongly regulates the aquaculture and fish farming sectors to reduce or compensate their emissions (Andersen et al., 2013; DEPA, 2014; HELCOM, 2007). Here, seaweed shows potential for a positive contribution since the bioextraction capacity of nitrogen is greater than yearly emissions in 9 out of 11 districts (Table A.5).

When considering yearly phosphorus emissions in the 21 river basin districts, seaweed cultivation proved to have a better effect on nutrient balance. Phosphorus flows into marine water bodies mainly come from land (aggregated category of natural background, agriculture and scattered houses). The emission supply from this category alone is $69 \%$ of the total yearly net supply of phosphorus, which is $1.8 \mathrm{Gg}$ (Table A.4). When an average productivity of $150 \mathrm{Mg} \mathrm{DW} / \mathrm{km}^{2}$ is considered, 8 out of 21 districts are in condition 2, i.e. bioextracted nutrients exceed total nutrient supply (Table A.6). When considering only phosphorus emissions from fish farming and aquaculture, seaweed bioextraction is greater than inflow in 9 out of 11 districts (Table A.6).

In most Danish water basins, seaweed could be effectively contribute to the creation and maintenance of a nutrient balance that would significantly improve the quality of the aquatic environment, providing supportive conditions for conservation of natural marine ecosystems. Seaweed cultivation could be a stand-alone instrument in certain Danish river basin districts, while in others several alternative instruments may be considered in concert, for example mussel farming and differentiated regulation of fertilizer use by farmers according to retention aspects (Hasler et al., 2012). At present, seaweed cultivation is not constrained by the nutrient supply from manmade activities and blue growth business is therefore not restrained. Cultivation technology is expected to improve and productivity to double, which corresponds to a reduction in cultivated marine area from 10 to $5 \%$.

\section{Conclusions}

The first part of the study used LCA to quantify the impact of three seaweed biomass management scenarios. We proposed improving on the conventional aquatic eutrophication impact categories of ReCiPe and CML by including fate factors for a correct analysis of circular nutrient management. The use of seaweed biomass as fertilizer, i.e. the MaFe scenario, had the lowest environmental impact in terms of marine eutrophication ( $-32.29 \mathrm{~kg} \mathrm{~N}$ eq./Mg DW seaweed according to ReCiPe) and aquatic eutrophication $\left(-16.58 \mathrm{~kg} \mathrm{PO}_{4}^{3-}\right.$ eq./Mg DW seaweed according to $\mathrm{CML}$ ). However, the bioextractive capacity of seaweed influences all scenarios, which showed reduced impact on the above two categories. Freshwater eutrophication calculated in the conventional way showed that only the incineration scenario contributes to the reduction of impacts due to energy production, while the MaFe and landfill scenarios led to a worsening of environmental conditions. However, we discussed how to improve the freshwater eutrophication impact category to quantify the effect of seaweed in P-limited marine waters. In this way we were able to take into account the bioextractive capacity of seaweed and identify the circular management system (MaFe scenario) as the most promising of the three alternatives.

In the second part of the paper, the information obtained from LCA was completed by estimating the balance between manmade emissions and seaweed bioextraction. The balance showed that seaweed cultivation currently does not contribute significantly to the creation of circular nutrient management at national level. However, the estimated shortterm horizon is favourable for three Danish river basin districts, significantly supporting achievement of nitrogen reduction goals and balancing manmade emissions of phosphorus. However, on a national scale, seaweed used as fertilizer would not reduce nitrogen and phosphorus fertilizer imports by $>0.4 \%$ and $0.8 \%$, respectively.

In the long term, most Danish river basin districts would benefit from seaweed cultivation, which would effectively contribute to the creation and maintenance of nutrient balance for both nitrogen and phosphorus.

A study extending LCA to include a biorefinery step is underway. It addresses the potential for extraction of valuable components, such as energy carriers (methane and ethanol), while leaving the nutrients in the 
residues that can be used as fertilizer. Life Cycle Impact Assessment is extended to include the impact categories climate change and human toxicity, with the aim of assessing the environmental sustainability of future nutrient management systems for biobased production (Seghetta et al., 2016b). The method can be used to assess the size of sustainable blue biomass production according to location-specific yearly amounts of emission supply worldwide and it could be useful for assessing the environmental sustainability of offshore seaweed production systems in countries such as China, South Korea, Japan and the Philippines, which are currently the largest producers of seaweed biomass.

\section{Acknowledgements}

Financial support from the Danish Council for Strategic Research (project no. 11-116872) via the MacroAlgaeBiorefinery (MAB3) project and the Graduate School of Science and Technology, Aarhus University, is gratefully acknowledged. The authors thank Professor Jens Kjerulf Pedersen, head of the Danish Shellfish Centre, Peter Schmedes and Teis Boderskov from Hjarnø Havbrug A/S and Michael Bo Rasmussen (Aarhus University, Denmark) for guided tours and fieldwork-supporting information on the seaweed cultivation system.

\section{Appendix A}

Table A.1

Emissions from disposal of municipal solid waste (22.9\% water) to landfill as reported in Ecoinvent database (Weidema et al., 2013).

\begin{tabular}{|c|c|c|c|c|c|c|}
\hline & Amount & U.M./1 kg WW & Sub-compartment/transport & \multicolumn{2}{|c|}{ Emission factor } & Notes \\
\hline \multicolumn{7}{|l|}{ Waste composition } \\
\hline $\mathrm{N}$ & 0.003123 & $\mathrm{~kg}$ & & & & \\
\hline $\mathrm{P}$ & 0.000894 & $\mathrm{~kg}$ & & & & \\
\hline \multicolumn{7}{|l|}{ Emissions to air } \\
\hline Ammonia & $1.41 \mathrm{E}-06$ & $\mathrm{~kg}$ & & 0.0005 & $\mathrm{~kg} / \mathrm{kg} \mathrm{N}$ & a \\
\hline Dinitrogen monoxide & $3.88 \mathrm{E}-06$ & $\mathrm{~kg}$ & & 0.0012 & $\mathrm{~kg} / \mathrm{kg} \mathrm{N}$ & a \\
\hline Nitrogen oxides & $1.37 \mathrm{E}-05$ & $\mathrm{~kg}$ & & 0.0001 & $\mathrm{~kg} / \mathrm{kg} \mathrm{N}$ & $\mathrm{a}$ \\
\hline Nitrogen oxides & $4.07 \mathrm{E}-07$ & $\mathrm{~kg}$ & & 0.0044 & $\mathrm{~kg} / \mathrm{kg} \mathrm{N}$ & b \\
\hline Phosphorus & $8.6 \mathrm{E}-09$ & $\mathrm{~kg}$ & & 0.0000 & $\mathrm{~kg} / \mathrm{kg} \mathrm{P}$ & $\mathrm{a}$ \\
\hline Cyanide & $3.95 \mathrm{E}-08$ & $\mathrm{~kg}$ & & 0.0000 & $\mathrm{~kg} / \mathrm{kg} \mathrm{N}$ & $\mathrm{a}$ \\
\hline \multicolumn{7}{|l|}{ Emissions to water } \\
\hline Ammonium, ion & $6.31 \mathrm{E}-04$ & $\mathrm{~kg}$ & Groundwater & 0.2020 & $\mathrm{~kg} / \mathrm{kg} \mathrm{N}$ & c \\
\hline Ammonium, ion & $7.63 \mathrm{E}-04$ & $\mathrm{~kg}$ & River & 0.2443 & $\mathrm{~kg} / \mathrm{kg} \mathrm{N}$ & a \\
\hline Nitrate & $6.80 \mathrm{E}-05$ & $\mathrm{~kg}$ & Groundwater, long-term & 0.0218 & $\mathrm{~kg} / \mathrm{kg} \mathrm{N}$ & c \\
\hline Nitrate & $2.78 \mathrm{E}-03$ & $\mathrm{~kg}$ & River & 0.8902 & $\mathrm{~kg} / \mathrm{kg} \mathrm{N}$ & $\mathrm{a}$ \\
\hline Nitrite & $3.44 \mathrm{E}-05$ & $\mathrm{~kg}$ & Groundwater & 0.0110 & $\mathrm{~kg} / \mathrm{kg} \mathrm{N}$ & c \\
\hline Nitrite & $1.60 \mathrm{E}-05$ & $\mathrm{~kg}$ & River & 0.0051 & $\mathrm{~kg} / \mathrm{kg} \mathrm{N}$ & a \\
\hline Nitrogen & $2.07 \mathrm{E}-05$ & $\mathrm{~kg}$ & River & 0.0066 & $\mathrm{~kg} / \mathrm{kg} \mathrm{N}$ & a \\
\hline Nitrogen, organic bound & $1.03 \mathrm{E}-03$ & $\mathrm{~kg}$ & Groundwater, long-term & 0.3298 & $\mathrm{~kg} / \mathrm{kg} \mathrm{N}$ & c \\
\hline Phosphate & $1.93 \mathrm{E}-05$ & $\mathrm{~kg}$ & Groundwater, long-term & 0.0216 & $\mathrm{~kg} / \mathrm{kg} \mathrm{P}$ & c \\
\hline Phosphate & $1.46 \mathrm{E}-05$ & $\mathrm{~kg}$ & River & 0.0163 & $\mathrm{~kg} / \mathrm{kg} \mathrm{P}$ & a \\
\hline
\end{tabular}

a Emissions from short-term percolate treatment and incineration of resulting sludge.

b Direct release or incineration of landfill biogas.

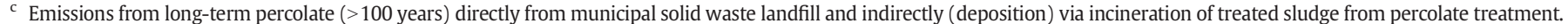

Table A.2

Emissions from pretreatment and incineration of digested sludge (95\% water) at a municipal incineration plant as reported in the Ecoinvent database (Weidema et al., 2013).

\begin{tabular}{|c|c|c|c|c|c|c|}
\hline & Amount & U.M./1 kg WW & Sub-compartment & \multicolumn{2}{|c|}{ Emission factor } & Notes \\
\hline \multicolumn{7}{|l|}{ Waste composition } \\
\hline $\mathrm{N}$ & $5.78 \mathrm{E}-03$ & $\mathrm{~kg}$ & & & & \\
\hline $\mathrm{P}$ & $8.62 \mathrm{E}-03$ & $\mathrm{~kg}$ & & & & \\
\hline \multicolumn{7}{|l|}{ Emissions to air } \\
\hline Ammonia & $2.04 \mathrm{E}-06$ & $\mathrm{~kg}$ & & 0.0004 & $\mathrm{~kg} / \mathrm{kg} \mathrm{N}$ & a \\
\hline Dinitrogen monoxide & $6.82 \mathrm{E}-06$ & $\mathrm{~kg}$ & & 0.0012 & $\mathrm{~kg} / \mathrm{kg} \mathrm{N}$ & a \\
\hline Nitrogen oxides & $4.40 \mathrm{E}-05$ & $\mathrm{~kg}$ & & 0.0076 & $\mathrm{~kg} / \mathrm{kg} \mathrm{N}$ & $\mathrm{a}$ \\
\hline Phosphorus & $1.55 \mathrm{E}-06$ & $\mathrm{~kg}$ & & 0.0002 & $\mathrm{~kg} / \mathrm{kg} \mathrm{P}$ & b \\
\hline Cyanide & 9.33E-07 & $\mathrm{kg}$ & & 0.0002 & $\mathrm{~kg} / \mathrm{kg} \mathrm{N}$ & $\mathrm{b}$ \\
\hline \multicolumn{7}{|l|}{ Emission to water } \\
\hline Ammonium, ion & $2.68 \mathrm{E}-04$ & $\mathrm{~kg}$ & River & 0.0463 & $\mathrm{~kg} / \mathrm{kg} \mathrm{N}$ & a \\
\hline Nitrate & 3.73E-05 & $\mathrm{kg}$ & Groundwater & 0.0064 & $\mathrm{~kg} / \mathrm{kg} \mathrm{N}$ & b \\
\hline Nitrate & $1.23 \mathrm{E}-03$ & $\mathrm{~kg}$ & River & 0.2124 & $\mathrm{~kg} / \mathrm{kg} \mathrm{N}$ & $\mathrm{a}$ \\
\hline Nitrogen & $1.84 \mathrm{E}-05$ & $\mathrm{~kg}$ & River & 0.0032 & $\mathrm{~kg} / \mathrm{kg} \mathrm{N}$ & $\mathrm{b}$ \\
\hline Phosphate & $1.45 \mathrm{E}-05$ & $\mathrm{~kg}$ & River & 0.0017 & $\mathrm{~kg} / \mathrm{kg} \mathrm{P}$ & a \\
\hline Phosphate & $1.81 \mathrm{E}-04$ & $\mathrm{~kg}$ & Groundwater & 0.0210 & $\mathrm{~kg} / \mathrm{kg} \mathrm{P}$ & $\mathrm{b}$ \\
\hline
\end{tabular}

a Emission from dewatering of digested sludge prior to incineration.

b Emission from sludge incineration. 
Table A.3

Sectoral nitrogen emissions to freshwater systems in the 21 Danish water districts, retention and net supply to the associated marine water bodies ${ }^{\mathrm{a}}$.

\begin{tabular}{|c|c|c|c|c|c|c|c|c|c|c|c|}
\hline \multirow{2}{*}{$\begin{array}{l}\text { River basin } \\
\text { district }\end{array}$} & \multirow{2}{*}{$\begin{array}{l}\text { Marine water body } \\
\text { surface area }\left(\mathrm{km}^{2}\right)\end{array}$} & \multicolumn{10}{|c|}{ Amount of nitrogen (Mg N/year) } \\
\hline & & $\begin{array}{l}\text { Natural } \\
\text { background }\end{array}$ & Agriculture & WWTP & Rainwat. & Industry & $\begin{array}{l}\text { Scattered } \\
\text { houses }\end{array}$ & $\begin{array}{l}\text { Fish } \\
\text { farm }\end{array}$ & Aquacult. & Retention & $\begin{array}{l}\text { Net } \\
\text { supply }^{\mathrm{b}}\end{array}$ \\
\hline 1.1 & 7927 & 715 & 2599 & 131 & 27 & 142 & 30 & 11 & 66 & -45 & 2960 \\
\hline 1.2 & 3430 & 2629 & 9163 & 350 & 98 & 47 & 99 & 175 & 0.4 & -1106 & 8825 \\
\hline 1.3 & 46 & 147 & 816 & 42 & 11 & - & 7 & - & - & -33 & 844 \\
\hline 1.4 & 65 & 593 & 1444 & 96 & 29 & - & 24 & 92 & - & -191 & 1494 \\
\hline 1.5 & 26 & 1330 & 3265 & 213 & 51 & 6 & 52 & 79 & - & $-1,487$ & 2178 \\
\hline 1.6 & 3972 & 208 & 1026 & 35 & 3 & 10 & 9 & - & - & -170 & 912 \\
\hline 1.7 & 1679 & 261 & 473 & 184 & 31 & 0.4 & 13 & 0.4 & - & -140 & 562 \\
\hline 1.8 & 2892 & 1563 & 2812 & 45 & 41 & 10 & 36 & 214 & 44 & -348 & 2854 \\
\hline 1.9 & 460 & 261 & 732 & 96 & 4 & - & 18 & 1 & 13 & -123 & 740 \\
\hline 1.10 & 2374 & 2129 & 6085 & 235 & 54 & 2 & 58 & 221 & - & -305 & 6349 \\
\hline 1.11 & 1221 & 1213 & 2967 & 355 & 59 & 6 & 67 & 61 & 47 & -338 & 3225 \\
\hline 1.12 & 1439 & 337 & 1020 & 60 & 19 & - & 24 & - & - & -11 & 1112 \\
\hline 1.13 & 457 & 388 & 1241 & 132 & 26 & 3 & 37 & - & - & -2 & 1437 \\
\hline 1.14 & 1418 & 146 & 482 & 44 & 8 & - & 20 & - & - & -15 & 539 \\
\hline 1.15 & 830 & 276 & 886 & 45 & 10 & - & 25 & - & - & -9 & 957 \\
\hline 2.1 & 2232 & 140 & 952 & 100 & 14 & 12 & 30 & - & 2 & -344 & 765 \\
\hline 2.2 & 439 & 308 & 2063 & 205 & 48 & 2 & 50 & - & - & -914 & 1453 \\
\hline 2.3 & 1920 & 116 & 397 & 580 & 34 & 19 & 13 & - & - & -136 & 906 \\
\hline 2.4 & 742 & 214 & 994 & 216 & 90 & 26 & 38 & - & - & -76 & 1288 \\
\hline 2.5 & 2175 & 1065 & 4591 & 234 & 73 & 44 & 160 & - & 110 & -1030 & 4182 \\
\hline 2.6 & 3665 & 300 & 1387 & 70 & 13 & 1 & 56 & - & - & -24 & 1503 \\
\hline Total & 39,410 & 14,339 & 45,395 & 3,465 & 743 & 329 & 866 & 853 & 283 & -6848 & 45,085 \\
\hline
\end{tabular}

a NA (2013a-u).

b The net supply is the sum of yearly emissions from the eight sectors minus retention.

Table A.4

Sectoral phosphorous emissions to freshwater systems in the 21 Danish water districts, retention and net supply to the associated marine water bodies ${ }^{\mathrm{a}}$.

\begin{tabular}{|c|c|c|c|c|c|c|c|c|c|}
\hline \multirow[t]{2}{*}{ River basin district } & \multirow{2}{*}{$\begin{array}{l}\text { Marine water body } \\
\text { surface area }\left(\mathrm{km}^{2}\right)\end{array}$} & \multicolumn{8}{|c|}{ Amount of phosphorus (Mg P/year) } \\
\hline & & Total land contributions & WWTP & Rainwater & Industry & Fish farm & Aquaculture & Retention & Net supply \\
\hline 1.1 & 7927 & 134 & 11.9 & 6.6 & 3.9 & 0.7 & 4.7 & -0.6 & 161 \\
\hline 1.2 & 3430 & 284 & 24.2 & 24.6 & 5.2 & 14.5 & - & -19.8 & 333 \\
\hline 1.3 & 46 & 13 & 1.2 & 2.7 & - & - & - & -0.2 & 17 \\
\hline 1.4 & 65 & 43 & 6.0 & 5.7 & - & 7.7 & - & -3.5 & 59 \\
\hline 1.5 & 26 & 102 & 11.9 & 12.1 & 0.2 & 6.0 & - & -32.7 & 100 \\
\hline 1.6 & 3972 & 21 & 3.4 & 0.7 & 0.3 & - & - & -1.1 & 24 \\
\hline 1.7 & 1679 & 16 & 8.4 & 7.1 & 0.1 & 0.1 & - & -2.8 & 29 \\
\hline 1.8 & 2892 & 86 & 4.0 & 9.8 & 1.2 & 17.9 & 3.4 & -8.9 & 114 \\
\hline 1.9 & 460 & 15 & 2.3 & 3.6 & - & 0.1 & 1.4 & -1.5 & 21 \\
\hline 1.10 & 2374 & 195 & 27.9 & 13.1 & 0.1 & 16.4 & - & -7.0 & 246 \\
\hline 1.11 & 1221 & 83 & 35.4 & 14.9 & 0.8 & 5.1 & 4.9 & -2.4 & 142 \\
\hline 1.12 & 1439 & 37 & 6.0 & 4.6 & - & - & - & -0.2 & 48 \\
\hline 1.13 & 457 & 43 & 5.2 & 6.5 & 0.1 & - & - & -0.1 & 55 \\
\hline 1.14 & 1418 & 17 & 4.8 & 1.7 & - & - & - & -0.3 & 23 \\
\hline 1.15 & 830 & 30 & 5.3 & 2.0 & - & - & - & -0.2 & 37 \\
\hline 2.1 & 2232 & 17 & 9.9 & 3.3 & 0.3 & - & 0.1 & -5.4 & 25 \\
\hline 2.2 & 439 & 29 & 25.4 & 11.5 & 0.1 & - & - & -7.7 & 58 \\
\hline 2.3 & 1920 & 19 & 120.3 & 13.8 & 0.8 & - & - & -5.1 & 149 \\
\hline 2.4 & 742 & 22 & 35.2 & 21.0 & 2.0 & - & - & -3.7 & 76 \\
\hline 2.5 & 2175 & 74 & 27.0 & 18.0 & 3.0 & - & 12.0 & -8.0 & 126 \\
\hline 2.6 & 3665 & 19 & 8.0 & 3.0 & - & - & - & - & 30 \\
\hline Total & 39,410 & 1301 & 383.5 & 186.2 & 18.0 & 68.4 & 26.5 & -111.2 & 1873 \\
\hline
\end{tabular}

a (NA (2013a-u).

b The net supply is the sum of yearly emissions from the six sources minus retention. 
Table A.5

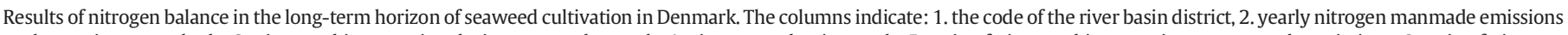

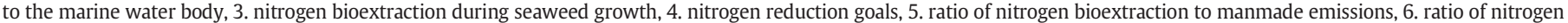
bioextraction to reduction goals, 7. ratio of nitrogen bioextraction to sum of emissions from fish farming and aquaculture.

\begin{tabular}{|c|c|c|c|c|c|c|}
\hline $\begin{array}{l}\text { River basin } \\
\text { district }\end{array}$ & $\begin{array}{l}\text { N manmade emissions } \\
(\mathrm{Mg} \mathrm{N})\end{array}$ & $\begin{array}{l}\text { Bioextraction } \\
(\mathrm{Mg} \mathrm{N})\end{array}$ & $\begin{array}{l}\text { Reduction goal } \\
(\mathrm{Mg})\end{array}$ & $\begin{array}{l}\text { Bioextra. N/manmade } \\
\text { emissions }\end{array}$ & $\begin{array}{l}\text { Bioextra. N/Reduction } \\
\text { goal }\end{array}$ & $\begin{array}{l}\text { Bioextra. } \mathrm{N} /(\text { fish far. } \\
+ \text { aquacult.) }\end{array}$ \\
\hline 1.1 & 3675 & 3858 & 294 & $>100 \%$ & $>100 \%$ & $>100 \%$ \\
\hline 1.2 & 11,455 & 1670 & 6300 & $19 \%$ & $27 \%$ & $>100 \%$ \\
\hline 1.3 & 991 & 22 & 436 & $3 \%$ & $5 \%$ & \\
\hline 1.4 & 2087 & 31 & 605 & $2 \%$ & $5 \%$ & $34 \%$ \\
\hline 1.5 & 3508 & 13 & 1509 & $1 \%$ & $1 \%$ & $16 \%$ \\
\hline 1.6 & 1120 & 1933 & 112 & $>100 \%$ & $>100 \%$ & \\
\hline 1.7 & 823 & 817 & 214 & $>100 \%$ & $>100 \%$ & $>100 \%$ \\
\hline 1.8 & 4417 & 1407 & 1016 & $49 \%$ & $>100 \%$ & $>100 \%$ \\
\hline 1.9 & 1001 & 224 & 370 & $30 \%$ & $60 \%$ & $>100 \%$ \\
\hline 1.10 & 8478 & 1,156 & 1187 & $18 \%$ & $97 \%$ & $>100 \%$ \\
\hline 1.11 & 4438 & 595 & 1997 & $18 \%$ & $30 \%$ & $>100 \%$ \\
\hline 1.12 & 1449 & 700 & 319 & $63 \%$ & $>100 \%$ & \\
\hline 1.13 & 1825 & 222 & 712 & $15 \%$ & $31 \%$ & \\
\hline 1.14 & 685 & 690 & 116 & $>100 \%$ & $>100 \%$ & \\
\hline 1.15 & 1233 & 404 & 641 & $42 \%$ & $63 \%$ & \\
\hline 2.1 & 905 & 1087 & 181 & $>100 \%$ & $>100 \%$ & $>100 \%$ \\
\hline 2.2 & 1761 & 214 & 528 & $15 \%$ & $40 \%$ & \\
\hline 2.3 & 1022 & 935 & 31 & $>100 \%$ & $>100 \%$ & \\
\hline 2.4 & 1502 & 361 & 105 & $28 \%$ & $>100 \%$ & \\
\hline 2.5 & 5247 & 1059 & 2099 & $25 \%$ & $50 \%$ & $>100 \%$ \\
\hline 2.6 & 1803 & 1784 & 379 & $>100 \%$ & $>100 \%$ & \\
\hline Total & 59,424 & 19,183 & 19150 & & & \\
\hline
\end{tabular}

Table A.6

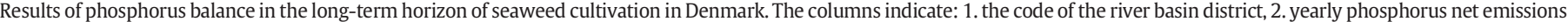

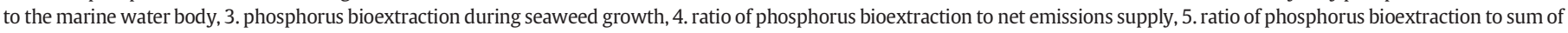
emissions from fish farming and aquaculture.

\begin{tabular}{|c|c|c|c|c|}
\hline River basin district & Net supply $(\mathrm{Mg} P)^{\mathrm{a}}$ & Bioextraction (Mg P) & Bioextra. P/Net supply & Bioextra. P/(fish far. + aquacult.) \\
\hline 1.1 & 161 & 347 & $>100 \%$ & $>100 \%$ \\
\hline 1.2 & 333 & 150 & $45 \%$ & $>100 \%$ \\
\hline 1.3 & 17 & 2 & $12 \%$ & \\
\hline 1.4 & 59 & 3 & $5 \%$ & $37 \%$ \\
\hline 1.5 & 100 & 1 & $1 \%$ & $19 \%$ \\
\hline 1.6 & 24 & 174 & $>100 \%$ & \\
\hline 1.7 & 29 & 74 & $>100 \%$ & $>100 \%$ \\
\hline 1.8 & 114 & 127 & $>100 \%$ & $>100 \%$ \\
\hline 1.9 & 21 & 20 & $96 \%$ & $>100 \%$ \\
\hline 1.10 & 246 & 104 & $42 \%$ & $>100 \%$ \\
\hline 1.11 & 142 & 53 & $38 \%$ & $>100 \%$ \\
\hline 1.12 & 48 & 63 & $>100 \%$ & \\
\hline 1.13 & 55 & 20 & $36 \%$ & \\
\hline 1.14 & 23 & 62 & $>100 \%$ & \\
\hline 1.15 & 37 & 36 & $98 \%$ & \\
\hline 2.1 & 25 & 98 & $>100 \%$ & $>100 \%$ \\
\hline 2.2 & 58 & 19 & $33 \%$ & \\
\hline 2.3 & 149 & 84 & $56 \%$ & \\
\hline 2.4 & 76 & 32 & $43 \%$ & \\
\hline 2.5 & 126 & 95 & $76 \%$ & $>100 \%$ \\
\hline 2.6 & 30 & 161 & $>100 \%$ & \\
\hline Total & 1873 & 1726 & & \\
\hline
\end{tabular}

a The net supply is the sum of yearly emissions from the six sources minus retention.

\section{References}

Statutory Order no. 1650 on the use of waste for agricultural purposes (Danish Title: "Bekendtgørelse om anvendelse af affald til jordbrugsformål"). Available at https://www.retsinformation.dk/forms/R0710.aspx?id=13056 (last accessed 01-04-2016).

Andersen, P. Carl, J., Dolmer, P., Leonhard, S.B., Kloppenborg-Skrumsager, B., 2013. Etablering af nyt havbrug ved Endelave. NATURA 2000 konsekvensredegørelse (English title: "Establishment of a new maricultural site at Endelave. NATURA 2000 Impact Statement"). Orbicon Report. Available at http://mst.dk/media/ mst/Attachments/EndelavehavbrugN2000konsekvensredegrelse_12122013H. pdf (01-04-2016).

BIM, Bord Iascaigh Mhara, 2014. The European market for sea vegetables. Report for "Farmed Irish Seaweed: An ocean wonder food?" Conference, p. 36.
Bruhn, A., Rasmussen, M.B., Larsen, M.M., Eybye, K.L., Tørring, D.B., Nielsen, K.O., 2015. Indholdsstoffer i Tang fra LIMFJORDEN (In eng: Substance content in seaweeds from Limfjorden). Vol. 16. Region Nordjylland Vækstforum, Fornyelses fonden.

Bruhn, A., Tørring, D.B., Thomsen, M., Canal-Vergés, P. Nielsen, M.M., Rasmussen, M.B. Eybye, K.L., Larsen, M.M., Petersen, J.K., 2016. Impact of Local Environmental Conditions on Biomass Yield and Quality of Saccharina latissima (in preparation).

Buschmann, A.H., Prescott, S., Potin, P., Faygeron, S., Vasquez, J.A., Camus, C., Infante, J., Hernandez-Gonzalez, M.C., Guyerrez, A., Varela, D.A., 2014. The status of kelp exploitation and marine agronomy, with emphasis on Macrocystis pyrifera, in Chile. Adv. Bot. Res. 71, 161-188.

Carlsson, A.S., van Beilen, J.B., Möller, R., Clayton, D., 2007. Micro- and Macro-algae: Utility for Industrial Applications. Outputs from the EPOBIO Project. CPL Press, Tall Gables, The Sydings, Speen, Newbury, Berks RG14 1RZ, UK, p. 86.

Christensen, Pia B., et al., 2013. Combined Uses - Marine Biomass from Offshore Wind Parks. SUBMARINER Report 11/2013 (http://publications.submariner-project.eu). 
COM, European commission, 2012. Communication from the Commission to the European Parliament, the Council, the European Economic and Social Committee and the Committee of the Regions Blue Growth Opportunities for Marine and Maritime Sustainable Growth. COM/2012/0494 Final.

Conley, D.J., Humborg, C., Rahm, L., Savchuk, O.P., Wulff, F., 2002. Hypoxia in the Baltic Sea and basin-scale changes in phosphorus biogeochemistry. Environ. Sci. Technol. 36, 5315-5320.

Conley, D.J., Paerl, H.W., Howarth, R.W., Boesch, D.F., Seitzinger, S.P., Havens, K.E., Lancelot, C., Likens, G.E., 2009. Controlling eutrophication: nitrogen and phosphorus. Science 323, 1014-1015.

Craigie, J.S., 2011. Seaweed extract stimuli in plant science and agriculture. J. Appl. Phycol. 23, 371-393.

DAFA, 2012. Danmarks Salg af Handelsgødning 2010/2011 (Eng. Sales of Fertilizer in Denmark 2010/2011). The Danish AgriFish Agency, Ministry of Food, Agriculture and Fisheries of Denmark, p. 18 (ISBN 978-87-7120-204-5 (Web)).

DAFA, 2013. Vejledning om Gødsknings og Harmoniregler (Eng. Guide on Fertilization and Harmony Rules). The Danish AgriFish Agency, Ministry of Food, Agriculture and Fisheries of Denmark, p. 153 (ISBN 978-87-7120-456-8).

DCE, 2015. Danish Centre for Environment and Energy. Denmark's national inventory report 2015 No. 171, pp. 915.

DEPA, 2014. Miljøgodkendelse: Hjarnø Havbrug A/S: Endelave (English title: "Environmental Approval Hjarnø Aquaculture A/S: Endelave"). Available at http://mst.dk/ media/mst/9186996/endelave_havbrug_milj_godkendelse.pdf (01-04-2016).

Directive 2000/60/EC of the European Parliament and of the Council of 23 October 2000. Establishing a Framework for Community Action in the Field of Water Policy. Official Journal of the European Communities.

DME, 2013. BEATE - Benchmarking af Affaldssektoren 2013, Deponering. Danish Ministry of the Environment, p. 19.

Dong, Y., Laurent, A., Hauschild, M.Z., 2013. Recommended Assessment Framework, Characterisation Models and Factors for Environmental Impacts and Resource Use.

Edwards, M., Watson, L., 2011. Cultivating Laminaria digitata. Aquaculture Explained No. 26Bord lascaigh Mhara, Irish Sea Fisheries Board, p. 72.

ESRI, 2011. ArcGIS Desktop: Release 10. Environmental Systems Research Institute, Redlands, CA.

Fredenslund, A.M., Gudmundsson, E., Møller, H.B., Fafner, K., Hjort-Gregersen, K., Kjær, L.L., Madsen, P.H., Danielsen, S., Christensen, T.B., Kjær, T., 2010. Udnyttelse af Tang og Restprodukter til Produktion af Biogas (in eng. Utilization of Seaweed and Residues to Produce Biogas). Solrød commune, technical administration, p. 78 (ISBN: 978-87-87949-01-9).

Goedkoop, M., Heijungs, R., Huijbregts, M., De Schryver, A., Struijs, J., van Zelm, R., 2013. ReCiPe 2008, a life cycle impact assessment method wich comprises harmonised category indicators at the midpoint and the endpoint level. Report 1, characterization. Ministry of housing, special planning and the environment, p. 133

Guinée, G., 2002. Handbook on Life Cycle Assessment, Operational Guide to the ISO Standards. Eco-Efficiency in Industry and Science Vol. 7. Springer, Netherlands, p. 692. http://dx.doi.org/10.1007/0-306-48055-7.

Haslam, S.F.I., Hopkins, D.W., 1996. Physical and biological effects of kelp (seaweed) added to soil. Appl. Soil Ecol. 3, 257-261.

Hasler, B., Smart, J.S., Fonnesbech-Wulff, A., 2012. Structure of BALTCOST Drainage Basin Scale Abatement Cost Minimization Model for Nutrient Reductions in Baltic Sea regions. Deliverable 8.1. The BONUS project RECOCA.

Heijungs, R., Guinée, J., Huppes, G., Lankreijer, R.M., Udo de Haes, H.A., Wegener Sleeswijk, A. Ansems, A.M.M., Eggels, P.G., van Duin, R., de Goede, H.P., 1992. Environmental Life Cycle Assessment of products. Guide and Backgrounds. CML, Leiden University, Leiden.

HELCOM, 2007. HELCOM Baltic Sea Action Plan. HELCOM Ministerial Meeting Krakow, Poland, 15 November 2007, p. 101 (Available at: http://helcom.fi/Documents/ Baltic\%20sea\%20action\%20plan/BSAP_Final.pdf (18-12-2014)).

Howarth, R.W., Marino, R., 2006. Nitrogen as the limiting nutrient for eutrophication in coastal marine ecosystems: evolving views over three decades. Limnol. Oceanogr. 51 (1, part 2), 364-376.

Jacobsen, B.H., 2012. Analyse af Omkostningerne ved en Yderligere Reduktion af N-tabet fra Landbruget med 10.000 tons N (in eng: Analysis of the Cost of a Further Reduction of N Losses from Agriculture by 10,000 tonnes N). Copenhagen University, Department of food and resource economics.

Jensen, M.D., Tychsen, P., Martinsen, L., Hasler, B., Thomsen, M., 2015. Bæredygtig udnyttelse af fosfor fra spildevand. En operativ vejledning til de danske vandselskaber (in eng: Sustainable Use of Phosphorus. An Operational Guidance to the Danish Water Companies). DEPA Report No. 1661 p. 116.

Kaspersen, B.S., Christensen, T.B., Fedenslund, A.M., Møller, H.B., Butts, M.B., Jensen, N.H., Kjaer, T., 2016. Linking climate change mitigation and coastal eutrophication management through biogas technology: evidence from a new Danish bioenergy concept. Sci. Total Environ. 541, 1124-1131.

Klepper, O., Beusen, A.H.W., Meinardi, C.R., 1995. Modelling the flow of nitrogen and phosphor in Europe: from loads to coastal seas (RIVM report 461501004). Bilthoven (the Netherlands). National Institute of Public Health and Environmental Protection (RIVM).

Lane, C.E., Mayes, C., Druehl, L.D., Saunders, G.W., 2006. A multi-gene molecular investigation of the kelp (Laminariales, Phaeophyceae) supports substantial taxonomic reorganization. J. Phycol. 42, 493-512.

Manns, D., Deutschle, A., Saake, B., Meyer, A.S., 2014. Methodology for quantitative determination of the carbohydrate composition of brown seaweeds (Laminariaceae). RSC Adv, 4, 25736-25746.

Mouritsen, O.G., 2013. Seaweeds: Edible, Available, and Sustainable. University of Chicago Press, p. 287 (ISBN 022604436X, 9780226044361).

N'Yeurt, A. de R., Chynoweth, D.P., Capron, M.E., Stewart, J.R., Hasan, M.A., 2012. Negative carbon via ocean afforestation. Process Saf. Environ. Prot. 90, 467-474.
NA, Nature Agency, 2013a. Forslag til vandplan - Hovedvandopland 1.1. Nordlige Kattegat og Skagerrak. Available at http://eng.naturstyrelsen.dk (18-12-2014).

NA, Nature Agency, 2013b. Forslag til vandplan - Hovedvandopland 1.2. Limfjorden Available at http://eng.naturstyrelsen.dk/ (18-12-2014).

NA, Nature Agency, 2013c. Forslag til vandplan - Hovedvandopland 1.3. Mariager Fjord Available at http://eng.naturstyrelsen.dk (18-12-2014).

NA, Nature Agency, 2013d. Forslag til vandplan - Hovedvandopland 1.4. Nissum Fjord Available at http://eng.naturstyrelsen.dk/ (18-12-2014)

NA, Nature Agency, 2013e. Forslag til vandplan - Hovedvandopland 1.5. Randers Fjord. Available at http://eng.naturstyrelsen.dk/ (18-12-2014)

NA, Nature Agency, 2013f. Forslag til vandplan - Hovedvandopland 1.6. Djursland. Available at http://eng.naturstyrelsen.dk (18-12-2014).

NA, Nature Agency, 2013g. Forslag til vandplan - Hovedvandopland 1.7. Aarhus Bugt. Available at http://eng.naturstyrelsen.dk (18-12-2014).

NA, Nature Agency, 2013h. Forslag til vandplan - Hovedvandopland 1.8. Ringkøbing Fjord. Available at http://eng.naturstyrelsen.dk (18-12-2014).

NA, Nature Agency, 2013i. Forslag til vandplan - Hovedvandopland 1.9. Horsens Fjord. Available at http://eng.naturstyrelsen.dk (18-12-2014).

NA, Nature Agency, 2013j. Forslag til vandplan - Hovedvandopland 1.10. Vandhavet. Available at http://eng.naturstyrelsen.dk (18-12-2014).

NA, Nature Agency, 2013k. Forslag til vandplan - Hovedvandopland 1.11. Lillebælt Jylland. Available at http://eng.naturstyrelsen.dk (18-12-2014).

NA, Nature Agency, 2013l. Forslag til vandplan - Hovedvandopland 1.12. Lillebælt Fyn. Available at http://eng.naturstyrelsen.dk (18-12-2014).

NA, Nature Agency, 2013m. Forslag til vandplan - Hovedvandopland 1.13. Odense Fjord. Available at http://eng.naturstyrelsen.dk (18-12-2014).

NA, Nature Agency, 2013n. Forslag til vandplan - Hovedvandopland 1.14. Storebælt Available at http://eng.naturstyrelsen.dk (18-12-2014).

NA, Nature Agency, 2013o. Forslag til vandplan - Hovedvandopland 1.15. Det Sydfynske Øhav. Available at http://eng.naturstyrelsen.dk (18-12-2014).

NA, Nature Agency, 2013p. Forslag til vandplan - Hovedvandopland 2.1. Kalundborg Available at http://eng.naturstyrelsen.dk (18-12-2014).

NA, Nature Agency, 2013q. Forslag til vandplan - Hovedvandopland 2.2. Isefjord og Roskilde Fjord. Available at http://eng.naturstyrelsen.dk (18-12-2014).

NA, Nature Agency, 2013r. Forslag til vandplan - Hovedvandopland 2.3. Øresund. Available at http://eng.naturstyrelsen.dk (18-12-2014).

NA, Nature Agency, 2013s. Forslag til vandplan - Hovedvandopland 2.4. Køge Bugt. Available at http://eng.naturstyrelsen.dk (18-12-2014).

NA, Nature Agency, 2013t. Forslag til vandplan - Hovedvandopland 2.5 Smålandsfarvandet. Available at http://eng.naturstyrelsen.dk (18-12-2014).

NA, Nature Agency, 2013u. Forslag til vandplan - Hovedvandopland 2.6. Østersøen. Available at http://eng.naturstyrelsen.dk (18-12-2014).

Nellemann, C., Corcoran, E., Duarte, C.M., 2009. Blue Carbon. A Rapid Response Assessment. United Nations Environment Programme, GRID-Arendal (ISBN: 978-82-7701060-1).

Nielsen, M.M., Manns, D., D'Este, M., Krause-Jensen, D., Rasmussen, M.B., Larsen, M.M. Alvarado-Morales, M., Angelidaki, I., Bruhn, A., 2016. Variation in biochemical composition of Saccharina latissima and Laminaria digitata along an estuarine salinity gradient in inner Danish waters. Algal Res. 13, 235-245.

Niero, M., Pizzol, M., Bruun, H.G., Thomsen, M., 2014. Comparative life cycle assessment of wastewater treatment in Denmark including sensitivity and uncertainty analysis. J. Clean. Prod. 68, 25-35.

PRé Consultants, 2008. Introduction to LCA with SimaPro. Product Ecology Consultants (February).

Quilliam, R.S., van Niekerk, M.A., Chadwick, D.R., Cross, P., Hanley, N., Jones, D.L., Vinten A.J.A., Willby, N., Oliver, D.M., 2015. Can macrophyte harvesting from eutrophic water close the loop on nutrient loss from agricultural land? J. Environ. Manag. $152,210-217$.

Reith, J.H., Kamermans, P., Brandeburg, W., Zeeman, G., 2005. Grootschalige teelt van zeewieren in combinatie met offshore windparken in de Noordzee (In eng: Largescale cultivation of seaweeds in combination with offshore wind farms in the North Sea). ECN-C-05-008. Energy research center of the Netherlands (ECN), p. 137.

Reith, J.H., van Hal, J.W., Lenstra, W.J., 2012. Large-scale Carbon Recycling via Cultivation and Biorefinery of Seaweeds for Production of Biobased Chemicals and Fuels. ECNL-12-054Energy research center of the Netherlands (ECN).

Schindler, D.W., Hecky, R.E., Findlay, D.L., Stainton, M.P., Parker, B.R., Paterson, M.J., Beaty, K.G., Lyng, M., Kasian, S.E.M., 2008. Eutrophication of lakes cannot be controlled by reducing nitrogen input: results of a 37 -year whole-ecosystem experiment. Proc. Natl. Acad. Sci. 105 (32), 11254-11258.

Seghetta, M., Marchi, M., Bastianoni, S., Bjerre, A.B., Thomsen, M., 2016c. Modelling Biogenic Carbon Flow in a Macroalgal Biorefinery System. Ecological Modelling X, XX (submitted for publication)

Seghetta, M., Romeo, D., D'Este, M., Alvarado-Morales, M., Angelidaki, I., Thomsen, M. 2016a. Macroalgae as a New Source of Energy and Feed in Denmark, Evaluating the Environmental Impacts Through LCA. Journal of cleaner production (submitted for publication).

Seghetta, M., Bastianoni, S., Bjerre, A.B., Thomsen, M., 2016b. Life Cycle Assessment of Macroalgae Biorefinery for the Production of Ethanol, Proteins and Fertilizers - A Step Towards a Regenerative Bioeconomy. Journal of Cleaner Production X, XX (submitted for publication)

Seghetta, M., Bastianoni, S., Østergaard, H., 2014. Energy analysis of using macroalgae from eutrophic waters as a bioethanol feedstock. Ecol. Model. 288, 25-37.

Skjermo, J., Aasen, I.M., Arff, J., Broch, O.J., Carvajal, A., Christie, H., Forbord, S., Olsen, Y., Reitan, K.I., Rustad, T., Sandquist, J., Solbakken, R., Steinhovden, K.B., Wittgens, B. Wolff, R., Handå, A., 2014. A New Norwegian Bioeconomy Based on Cultivation and 
Processing of Seaweeds: Opportunities and R\&D Needs. Innovation Norway (ISBN 978-82-14-05712-6).

Sludge Directive 86/278/EEC on the Protection of the Environment, and in Particular of the Soil, When Sewage Sludge is Used in Agriculture. Official Journal of the European Communities.

Stumm, W., Morgan, J.J., 1981. Aquatic Chemistry - Introduction Emphasizing Chemical Equilibria in Natural Water. second ed. John Wiley \& Sons, New York.

Tambone, F., Scaglia, B., D'Imporzano, G., Schievano, A., Orzi, V., Salati, S., Adani, F., 2010. Assessing amendment and fertilizing properties of digestates from anaerobic digestion through a comparative study with digested sludge and compost. Chemosphere $81,577-583$.

Tørring, D., Oddershede-Nielsen, K., 2014. Manual til dyrkning af sukkertang (Saccharina latissima) i Limfjorden, Danmark (in English: Manual for Cultivation of Sugar Kelp (Saccharina latissima) in Limfjorden, Denmark). Dansk Skaldyrcenter, p. 12.

Villares, R., Carral, E., Lorenzana, F., López Mosquera, E., 2007. Drift-seaweed evaluation for fertilizer use in Galiza (Northwest Spain): tissue elemental characterization and site-sampling differences. J. Sustain. Agric. 31, 45-60.

Vinther, F.P., Olsen, P., 2014. Næringsstofbalancer og næringstofsoverskud i landbruget 1992/93-2012/13 (In eng: Nutrient Balance and Nutrient Surplus in Agriculture). DCA Report Nr.046DCA, National Center for Food and Agriculture, p. 32.
Weidema, B.P., Bauer, Ch., Hischier, R., Mutel, Ch., Nemecek, T., Reinhard, J., Vadenbo, C.O., Wernet, G., 2013. The ecoinvent database: overview and methodology, data quality guideline for the ecoinvent database version 3. www.ecoinvent.org.

Zhang, J., Hansen, P.K., Fang, J., Wang, W., Jiang, Z., 2009. Assessment of the local environmental impact of intensive marine shellfish and seaweed farming - application of the MOM system in the Sungo Bay, China. Aquaculture 287, 304-310.

\section{WEB references}

http://www.atsea-project.eu [Last accessed 01-04-2016]

http://www.biomara.org/[Last accessed 01-04-2016]

http://www.enalgae.eu [Last accessed 01-04-2016]

http://www.MAB3.dk [Last accessed 01-04-2016]

http://miljoegis.mim.dk/cbkort?\&profile=miljoegis_vandrammedirektiv2013-hoering [Last accessed 01-04-2016]

http://www.netalgae.eu [Last accessed 01-04-2016]

http://www.noordzeeboerderij.nl [Last accessed 01-04-2016]

http://www.submariner-project.eu [Last accessed 01-04-2016] 